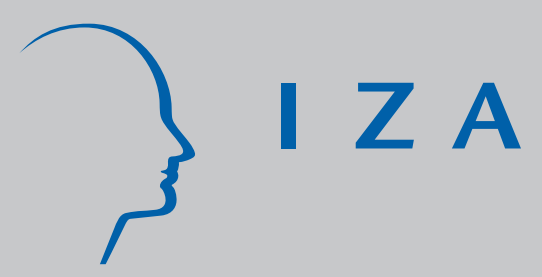

IZA DP No. 1322

Do Earnings Subsidies Affect Job Choice?

Helen Connolly

Peter Gottschalk

September 2004 


\title{
Do Earnings Subsidies \\ Affect Job Choice?
}

\author{
Helen Connolly \\ Northeastern University \\ Peter Gottschalk \\ Boston College and IZA Bonn
Discussion Paper No. 1322
September 2004

\author{
IZA \\ P.O. Box 7240 \\ 53072 Bonn \\ Germany \\ Phone: +49-228-3894-0 \\ Fax: +49-228-3894-180 \\ Email: iza@iza.org
}

Any opinions expressed here are those of the author(s) and not those of the institute. Research disseminated by IZA may include views on policy, but the institute itself takes no institutional policy positions.

The Institute for the Study of Labor (IZA) in Bonn is a local and virtual international research center and a place of communication between science, politics and business. IZA is an independent nonprofit company supported by Deutsche Post World Net. The center is associated with the University of Bonn and offers a stimulating research environment through its research networks, research support, and visitors and doctoral programs. IZA engages in (i) original and internationally competitive research in all fields of labor economics, (ii) development of policy concepts, and (iii) dissemination of research results and concepts to the interested public.

IZA Discussion Papers often represent preliminary work and are circulated to encourage discussion. Citation of such a paper should account for its provisional character. A revised version may be available directly from the author. 


\section{ABSTRACT \\ Do Earnings Subsidies Affect Job Choice?*}

It is widely acknowledged that tax and transfer policies can affect employment. This paper explores a different potential impact of transfer policy by asking whether subsidies also affect job duration and wage growth. We provide an analytical framework that identifies causal links between earnings subsidies, job turnover, and wage growth. This framework highlights the importance of the form of the subsidy on the decision about the type of job to accept and, hence, its potential effect on within-job wage growth. The subsidy is predicted to increase job turnover and to affect between-job wage growth by affecting reservation wages. We use this framework to analyze the effects of the Canadian Self-Sufficiency Project (SSP). Consistent with the predictions of the analytical framework, we find that experimentals have shorter job duration and experience faster wage growth than the controls, who continue to be eligible only for Income Assistance.

JEL Classification: J23, J38

Keywords: $\quad$ wage subsidy, job choice

Corresponding author:

Peter Gottschalk

Economics Department

Boston College

Chestnut Hill, MA 02467

USA

Email: peter.gottschalk@bc.edu

\footnotetext{
* This project was partially funded under grants from the Social Research and Demonstration Corporation and the Russell Sage Foundation. We thank Martin Dooley and participants at the Institute for Research on Poverty Summer Workshop; the Annual Meeting of the Canadian Economics Association; and the workshop at University College, London, for useful comments.
} 


\section{Do Earnings Subsidies Affect Job Choice?}

\section{The Impact of SSP Subsidies on Job Turnover and Wage Growth}

\section{Overview}

It is widely acknowledged that earnings subsidies promote employment by increasing rewards to labor market activity. This paper addresses the question of whether subsidies also alter the types of jobs held and the duration in these jobs. This question is especially important given the interest in earnings subsidies in Canada and the U.S. If subsidies encourage low-income workers to find jobs with higher within-job wage growth or jobs with greater wage growth between jobs, then subsidies may lead to self--sufficiency. ${ }^{1}$

While the analytical links between earnings subsidies and employment are well developed, the links between subsidies and the choice of jobs are less transparent. We, therefore, start by developing analytical links between the availability of an earnings subsidy and the type and duration of jobs individuals will accept. We then use data from a large Canadian earnings subsidy experiment to explore whether the replacement of an income assistance system by an earnings subsidy leads to differences in wage growth and job duration between experimentals and controls.

Our focus on the impact of earnings subsidies on wage growth and job duration stands in contrast to the previous literature that has focused primarily on the impact of earnings subsidies on labor supply decisions. ${ }^{2}$ By increasing the rewards to work, earnings subsidies induce some eligible participants to join the labor market and encourage others to increase the number of hours worked. These predictions about the effect of a subsidy on labor supply have been strongly supported by the data. ${ }^{3}$ By themselves, these labor supply effects will lead to higher earnings, but not necessarily to greater wage growth. Our empirical results indicate that experimentals who are eligible for an earnings subsidy have greater job turnover and experience faster wage growth than do controls who continue to be covered by the original income transfer system.

This paper contains six sections. We start in Section 2 by developing a framework that provides the analytical links between wage subsidies and the decisions that affect wage growth. Section 3 provides a discussion of the estimation. Section 4 discusses the data available in the Canadian Self-Sufficiency project and Section 5 presents details of our results. Concluding remarks are in Section 6.

\footnotetext{
${ }^{1}$ See Mincer (1974) for the initial human capital model, and Heckman et al. (2003) and Lemieux (2003) for recent expansions on this seminal work. Heckman et al. (1998) and Gladden and Taber (2000) explore how investment in specific human capital can differ by skill level.

${ }^{2}$ There are two exceptions but both have different focus than our work. Card et al. (2001) estimates the impact of the SSP subsidy on wage growth of persons induced to work full time in order to qualify for the subsidy. The other is Heckman et al. (2002), which explores the impact of the Earned Income Tax Credit (EITC) on wage growth through its effect on human capital investment and learning-by-doing.

${ }^{3}$ See Michalopoulos et al. (2002).
} 


\section{Analytical Framework}

This section provides the conceptual links between program attributes and the economic factors that affect both the decision to search for a better job and the decision of which offer to accept.

\subsection{Within-job Wage Growth}

We start by considering whether offering a wage or earnings supplement can affect the choice between jobs with different wage profiles. ${ }^{4}$ In order to isolate the effects of wage growth on job choice, consider two jobs that have different wage paths (i.e., starting wages and expected wage growth), but are similar in terms of hours and expected job duration. Suppose workers choose between jobs on the basis of their expected wage streams. The question we ask is whether the introduction of a wage supplement affects the choice of jobs. For example, if a job with high initial wages but low wage growth has a higher present value than a job with a low starting wage but high wage growth, then it will be chosen in the absence of a subsidy. Can the availability of a wage subsidy reverse this job choice? If so, then the program induces workers to choose higher wage growth jobs.

Appendix A shows that the effect of the subsidy on job choice depends on the form of the mapping of pre-subsidy wages into post-subsidy wages. If the transformation is convex (concave) the person is more (less) likely to accept a job with wage growth when the supplement is available.

In the special case of a linear supplement, the wage subsidy has no affect on the threshold and, therefore, no effect on the type of job chosen. This is analytically equivalent to the result in the public finance literature that income-maximizing taxpayers are indifferent to the timing of income if the tax system is proportional. Jobs with constant wages (no wage growth) that would be accepted before the subsidy will still be accepted after the subsidy. Intuitively, a job with low starting wages and high wage growth will have a larger subsidy in the early periods and a smaller subsidy in the later periods. The job with low wage growth and higher starting wages will have a smaller supplement early on, but a larger supplement in the later periods when the wage in the high wage growth job starts exceeding the wages in the job with lower wage growth. If the subsidy is a linear function of pre-subsidy earnings, then the lower subsidies in the later periods will just offset the higher subsidies in the earlier periods. ${ }^{5}$

As we will show, the Self-Sufficiency Project (SSP) subsidy is effectively linear, but the Income Assistance (IA) transfer program it replaces is highly concave. ${ }^{6}$ This implies that IA discourages workers from taking jobs with low starting wages but high wage growth. Since SSP does not have this disincentive, SSP experimentals are expected to be more likely than IA controls to take jobs with low initial wages, but high wage growth.

\footnotetext{
${ }^{4}$ Wage and earnings supplements are analytically equivalent if hours are fixed.

${ }^{5}$ This prediction would have to be modified to take discounting or risk aversion into account, but the principle is the same.

${ }^{6}$ The EITC is also a concave mapping of pre-subsidy earnings into post-subsidy earnings.
} 


\subsection{Job Turnover and Between-job Wage Growth}

Earnings subsidies may also affect job duration and between-job wage growth by altering: (1) the decision to search for a new job, (2) the type of search (search on the job or while unemployed), and (3) the reservation wage. Changes in the decision to search and the type of search will affect job duration. The intuition for the relationship between subsidies and the decision to search on the job or while unemployed is straightforward. Subsidies increase the cost of searching while unemployed since refusing a wage offer and continuing to search results in losing both the offered wage and the subsidy. This increase in the cost of search increases the probability of accepting an offer and possibly continuing to search while on the job.

The effect of a wage subsidy on the expected wage gain between jobs, however, cannot be signed. As we will show, the subsidy increases the benefits of search by increasing the value of each subsidized offer, but the expected wage gain between jobs can increase or decrease.

To show this, we introduce an earnings supplement into the framework developed in Burdett (1978)'s classic article on the choice between full-time search and on-the-job search. In order to focus on essentials, we use a standard search framework in which agents are assumed to pay a fixed price to obtain draws from a known wage offer distribution. They must then decide whether to accept that wage or continue to search.

Let $f(w)$ be the distribution of wage offers and let $c_{f t s}$ and $c_{o j s}$ be the out-of-pocket costs of obtaining an offer while searching full-time (while unemployed) and while searching on the job, respectively. We follow Burdett (1978) in considering the case where out-of-pocket search costs are lower when searching full-time than when searching while holding another job (i.e., $\left.c_{f t s}<c_{o j s}\right) .^{7}$

We start by considering the decision, in the absence of a wage subsidy, whether to search and, if so, whether to search full-time or on the job. Burdett (1978) shows that there are three ranges of wages with different optimal decisions. In the absence of the subsidy, the marginal benefit of search is given by:

$$
H\left(w^{*}\right)=\frac{1}{r} \int_{w^{*}}\left(w-w^{*}\right) f(w) d w,
$$

where $r$ is the interest rate. As shown in Figure 1, marginal benefits decline with higher reservation wages since $\frac{\partial H\left(w^{*}\right)}{\partial w^{*}}=-\frac{1}{r}\left(1-F\left(W^{*}\right)\right)<0$ for all distributions. The marginal cost of full-time search is given by the sum of the out-of-pocket costs, $c_{f t s}$, and the opportunity cost of not working, $w^{*}$. This is shown as the upward-sloping cost function, $c_{f t s}+w^{*}$. Since the cost of searching while working, $c_{o j s}$, is independent of $w^{*}$, the cost of on-the-job search is shown as a horizontal line. These two cost functions determine two thresholds, $w_{1}^{*}$ and $w_{2}^{*}$. The first threshold, $w_{1}^{*}$, separates the region of full-time search from on-the-job search. At this point, the costs of the two search methods are equal:

$$
c_{o j s}=w_{1}^{*}+c_{f t s} .
$$

Full-time search is less costly than on-the-job search below this threshold. Above this threshold, the agent would search on the job rather than forego the offered wage.

\footnotetext{
${ }^{7}$ For a given wage offer distribution and arrival rate, full-time search is never an optimal choice if $c_{f t s}>c_{o j s}$. See Blau and Robins (1990) and Holzer (1987) for a discussion of alternative modes of search.
} 
Figure 1: The Impact of a Wage Subsidy on Full-time and On-the-Job Search

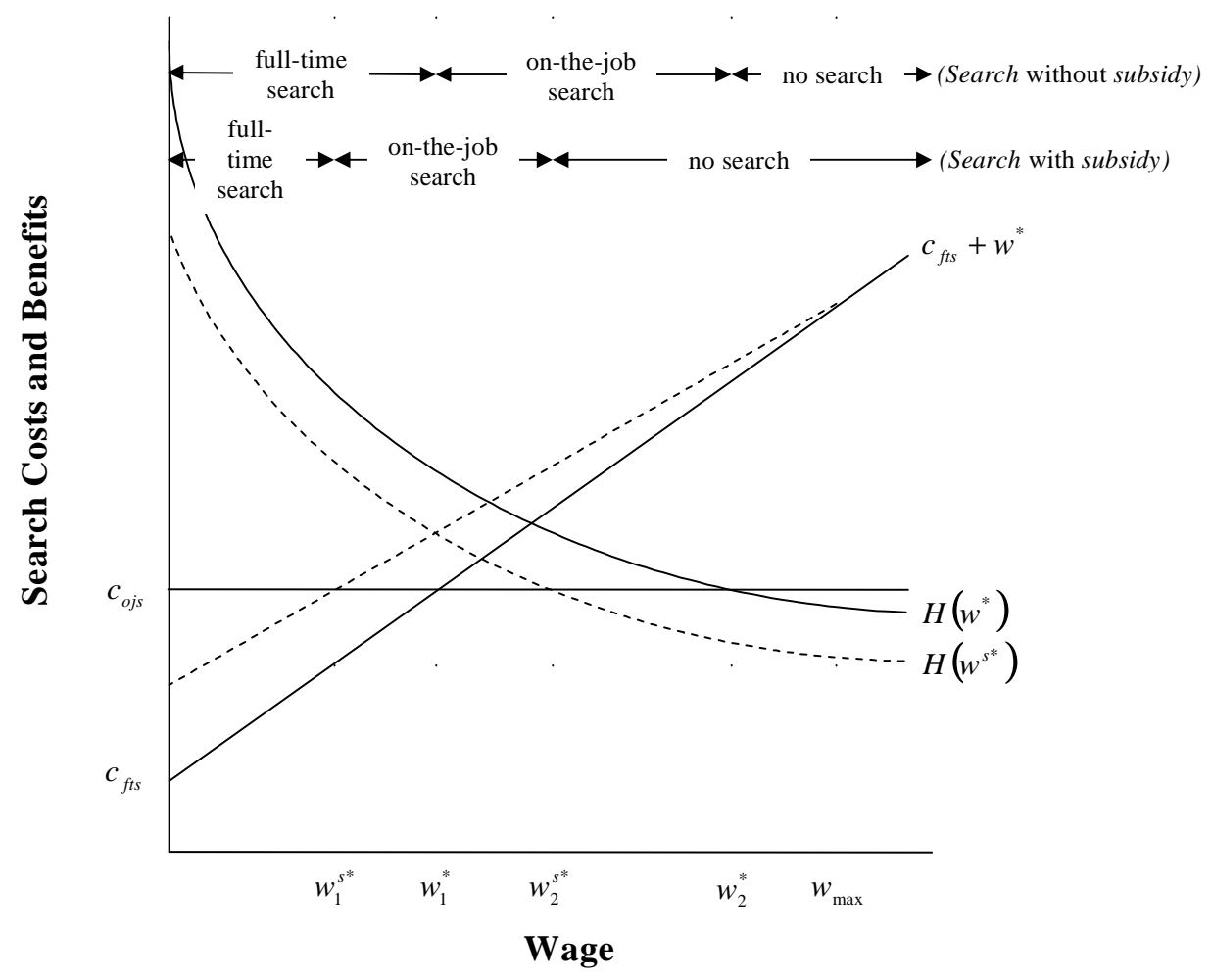

The decision whether to continue searching depends on the marginal costs and benefits of search. Search stops when wage offers exceed $w_{2}^{*}$, which is the point where the marginal costs and benefits of further on-the-job search are equal. This threshold is determined by the implicit expression:

$$
c_{o j s}=\frac{1}{r} \int_{w_{2}^{*}}\left(w-w_{2}^{*}\right) f(w) d w .
$$

In summary, Burdett shows that offers below $w_{1}^{*}$ are refused and the agent continues to search full time, with a reservation wage of $w_{1}^{*}$. Wage offers between $w_{1}^{*}$ and $w_{2}^{*}$ are accepted, but the agent continues to search while on the job with a reservation wage equal to the current wage, $w_{c}^{*}$. Wage offers above $w_{2}^{*}$ are accepted and the agent no longer searches. ${ }^{8}$

\footnotetext{
${ }^{8}$ Note that this model predicts that no agent would voluntarily quit to search full time unless the costs of search or the wage offer distribution changed. This does not mean that agents may not decide to voluntarily quit for other reasons. Inasmuch as the subsidy increases the opportunity costs of not working, it is expected to decrease these voluntary transitions to non-employment.
} 


\subsubsection{The Impact of a Wage Subsidy}

Now consider the impact of introducing a wage subsidy on the decision to search full time or on the job. ${ }^{9}$ Let $s(w)$ be the post-subsidy wage, which depends on the pre-subsidy wage, $w$. The cost of full-time search is increased since the opportunity cost of refusing an offer in order to continue full-time search now also includes the foregone subsidy that would have been received had the offer been accepted. This increase in the cost of full-time search is shown as an upward shift in the cost function for full-time search in Figure 1. Since on-the-job search does not involve an opportunity cost in terms of foregone wages, there is no change in this cost function. The increase in the cost of full-time search relative to on-the-job search reduces the threshold for searching on the job to $w_{1}^{s *}$, as illustrated in Figure 1. Thus, the earnings subsidy is predicted to increase the propensity to search while holding a job. ${ }^{10}$

Now consider the impact of the subsidy on the decision whether to search on the job or to stop searching. The benefits of search are decreased by the subsidy as long as the subsidy declines with wages, but is still positive at $w_{2}^{*}{ }^{11}$ The intuition for this result is that both the acceptable offers and the threshold are subsidized. However, since the threshold is lower than any acceptable wage, it receives a larger subsidy. As a result, the post-subsidy gain over the threshold is reduced. This reduction in the benefit of search is shown by the dashed benefit schedule in Figure 1. The decrease in the benefit of search lowers the threshold from $w_{2}^{*}$ to $w_{2}^{s *}$. As a result, some offers which would have led to further on-the-job search are now accepted without further search.

A direct implication of the reduction in $w_{1}^{*}$ and $w_{2}^{*}$ is that wage subsidies are predicted to decrease job duration. Let the hazard of leaving a job paying $w_{c}^{*}$ be given by $h\left(w_{c}^{*}\right)=\int_{w_{c}^{*}} f(w) d w$. Integrating over all possible jobs with on-the-job search (i.e., $w_{1}^{*}<w_{c}^{*}<w_{2}^{*}$ ) yields the hazard for a random person searching on-the-job:

$$
h\left(w_{1}^{*}, w_{2}^{*}\right)=\frac{\int_{w_{1}^{*}}^{w_{2}^{*}} h\left(w_{c}^{*}\right) f\left(w_{c}^{*}\right) d w_{c}^{*}}{\int_{w_{2}^{*}}^{w_{2}^{*}} f\left(w_{c}^{*}\right) d w_{c}^{*}} .
$$

\footnotetext{
${ }^{9}$ For analytical simplicity, we assume that the subsidy does not alter the wage offer distribution. However, if the subsidy is only available for full-time jobs and if the wage offer distribution for these jobs is different than for part-time jobs, then this is yet another way in which the program may affect search. While the SSP allows individuals to take multiple part-time jobs instead of one full-time job, many opt for full-time employment. For a discussion of general equilibrium effects of SSP see Lise et al. (2005).

${ }^{10}$ If the lower support of the wage offer distribution is set by the minimium wage, then $w_{1}^{s *}$ can never drop below the minimum wage. If $w_{1}^{*}$ is already at the minimum wage then the subsidy will not affect the reservation wage.

${ }^{11}$ The change in the benefit of search is given by:

$$
\begin{aligned}
\Delta H\left(w^{*}\right) & =H\left(w^{*}\right)-H\left(w^{s *}\right) \\
& =\frac{1}{r} \int_{w^{*}}\left(w-w^{*}\right) f(w) d w-\frac{1}{r} \int_{w^{*}}\left(s(w)-s\left(w^{*}\right)\right) f(w) d w \\
& =\frac{1}{r} \int_{w^{*}}\left\{[w-s(w)]-\left[w^{*}-s\left(w^{*}\right)\right]\right\} f(w) d w<0 .
\end{aligned}
$$

Both terms in brackets are negative, but if the subsidy declines with wages, the first term is smaller in absolute value than the second. Hence, the gains from search are reduced by the wage subsidy.
} 
It is straightforward to show that a decline in $w_{1}^{*}$ and $w_{2}^{*}$ increases $h\left(w_{1}^{*}, w_{2}^{*}\right)$ and, hence, decreases job duration. The intuition for this result is that persons who formerly searched while unemployed now search while holding low-paying jobs (i.e., those with $w_{1}^{s *}<w_{c}^{*}<w_{1}^{*}$ ). Given their low wages, they have higher hazards of leaving these jobs than persons with higher wages who searched on the job in the absence of the wage subsidy. At the other end of the wage spectrum, persons who would have searched on the job now no longer find it worthwhile to search (i.e., those with $w_{2}^{s *}<w_{c}^{*}<w_{2}^{*}$ ). Individuals with high wages have the lowest probability of finding jobs that lead to a job exit. The wage subsidy, therefore, increases the number of workers with high hazards of job exits and reduces the number with low hazards. As a result, the subsidy is predicted to increase the mean hazard and, hence, decrease expected job duration.

While it is possible to sign the impact of the wage subsidy on the two relevant thresholds and job duration, the impact on between-job wage gain cannot be signed. ${ }^{12}$ Therefore, earnings subsidies may either increase or decrease between-job wage gains depending on the wage offer distribution. Intuitively, the reduction in both $w_{1}^{*}$ and $w_{2}^{*}$ means that lower wages are accepted by persons searching on the job. This implies that on-the-job search occurs further down in the wage offer distribution. Some persons with low offers who would have searched while unemployed in the absence of a wage subsidy instead accept these offers and search on the job. In addition, some persons with higher offers who would have searched on the job in the absence of a wage subsidy now no longer search. The result is that persons searching on the job have lower average wages than in the absence of a subsidy. Since the current wage is the on-the-job reservation wage, this shift in the distribution of persons searching on the job lowers both the reservation wage and the mean acceptable offer. Whether the reservation wage or the mean acceptable offer decreases more depends on the form of the wage offer distribution.

In summary, we have shown that a wage subsidy is predicted to induce some persons to switch from full-time search to on-the-job search and some people to stop searching for a better job. This is the result of the subsidy increasing the opportunity cost of not accepting a wage which would make the person eligible for a subsidy and of the subsidy lowering the benefits of search. In addition we have shown that a wage subsidy is predicted to decrease job duration as persons initially accept jobs with low wages which are later dominated by better offers. While predictions can be made about the type of search and job duration, there is no general prediction about whether the subsidy will lead to larger or smaller mean change in wages between jobs. That remains an empirical issue.

\subsection{Application to the Self-Sufficiency Project}

While our analytical results are based on a generic earnings subsidy, we apply these results to a specific demonstration project that was instituted in two Canadian provinces. Since our empirical work requires a certain familiarity with the basic structure of this experiment, we start with a brief description of this demonstration project. ${ }^{13}$

\footnotetext{
${ }^{12}$ Proof that the impact of the subsidy on expected between-job wage change depends on the form of the wage offer distribution is available on request.

${ }^{13}$ For a full description of this program see Michalopoulos et al. (2002).
} 
The Canadian Self-Sufficiency Project (SSP) was designed to determine the impact of instituting an earnings supplement for welfare recipients in order to reduce the reliance on long-term Income Assistance (IA). The hope was that the subsidy would not only lead to an increase in labor supply, but also to jobs with higher wages. The key attribute of the program is that it provides time-limited income supplements to individuals who work full time and do not collect IA. ${ }^{14}$

The supplement was offered to a random sample of single parents in New Brunswick and British Columbia, aged 19 or over, who had been on IA for at least 12 of the previous 13 months. In order to collect the supplement, individuals in the selected experimental group were required to work full time (at least 30 hours a week) in one or more jobs within 12 months of becoming eligible for the program. ${ }^{15}$ The supplement was offered for a period of three years to each eligible individual and set so that most eligible families would find work to be financially preferable to continued receipt of IA. In addition to the supplement, program participants were provided with information sessions on the rules and benefits of the supplement. ${ }^{16}$

Supplement payments were based on earnings and were 50 percent of the difference between the individual's monthly earnings and a target earnings level each pay period. In 1993, the target earnings for an individual in New Brunswick was $\$ 2,500$ per month or $\$ 625$ per week. A person working 30 hours per week at $\$ 6$ per hour would, therefore earn $\$ 180$ per week and receive a supplement of $\$ 222$, which is the equivalent of subsidized wage of over $\$ 13$ per hour. The target earnings in British Columbia was $\$ 3,083$, which would result in a $\$ 295$ subsidy for someone working 30 hours per week at the minimum wage of $\$ 6$, which would result in an effective wage of close to $\$ 16$. The subsidy would, therefore, more than double the individual's earnings. ${ }^{17}$ She would, however, face a 50 percent benefit reduction against any increase in earnings, since the subsidy is equal to half the difference between actual earnings and the target earnings level.

Each eligible individual had 12 months from the time of eligibility to begin working full time and to start collecting SSP payments. These individuals could claim the supplement for a maximum of 36 consecutive months, starting the month they began collecting supplemental payments, but only during those months they were employed at least 30 hours per week. Those assigned to the SSP group could return to IA and/or cease working full time, but they could not collect the supplement during those months. They could resume receipt of the supplement in any month they worked full time during the three-year period.

\footnotetext{
${ }^{14}$ As noted earlier, however, experimentals in the SSP have the option of taking multiple part-time jobs instead of one full-time jobs.

${ }^{15} \mathrm{An}$ eligible job is one that is covered by Unemployment Insurance and pays at least the minimum wage. In 1993, the minimum wage was $\$ 5$ and $\$ 6$ in New Brunswick and British Columbia, respectively. Employers are not informed of an individual's SSP status.

${ }^{16}$ While participants were also offered some limited auxiliary services, these constituted a very small part of the program.

${ }^{17}$ The supplement payments are treated as regular income for tax purposes and are not affected by unearned income or by the income of a spouse or partner.
} 


\subsubsection{Comparison of the SSP Wage Subsidy to the IA Transfer System}

Our application requires that we compare the job choice of experimentals who were eligible for the SSP wage supplement with the job choice made by controls who were only eligible for the IA income transfer. The fact that both controls and experimentals were eligible for income transfers adds a level of complexity.

We start by considering the impact of the SSP subsidy on the job choice of experimentals. Under the SSP supplement a wage, $w$, is supplemented by half the difference between the wage and the target wage, $w_{\max }$. The supplemented wage, $s(w)$, is given by:

$$
s(w)=\left\{\begin{array}{ll}
=w+\left(\frac{w_{\max }-w}{2}\right)=\frac{1}{2}\left(w+w_{\max }\right), & \text { if } w<w_{\max } \\
=w, & \text { if } w \geq w_{\max }
\end{array}\right\} .
$$

The supplemented wage is, therefore, a linear function of the unsupplemented wage, $w$, up to $w_{\max }$ and is equal to $w$ above that threshold. Since few experimentals can expect to have wages rise above $\$ 20$ per hour, which is roughly the wage necessary to exceed the the earnings maximum for recipients working 30 hours a week, the subsidy is effectively linear. This implies that the SSP supplement has minimal effect on the choice of jobs compared to an unsubsidized job. ${ }^{18}$

Since the control group is eligible for IA transfers, we must also consider the impact of this program on job choice. IA recipients can earn up to $\$ 200$ per month without a reduction in benefits. Earnings above this level are, however, subject to a 100 percent benefit reduction rate. This implies that post-IA earnings are a concave function of pre-transfer earnings. This discourages IA recipients from taking jobs with low initial wages but high wage growth. This is a direct result of the fact that the wage gains are fully taxed once monthly earnings rise above $\$ 200 .^{19}$

Our analytical framework predicts that the replacement of IA by SSP may induce experimentals to take jobs with wage growth that would be less attractive to controls who receive IA. It should, however, be kept in mind that this is because SSP eliminates a disincentive in the IA program, not because SSP itself has a positive incentive. In other words, if SSP were made available to individuals who did not receive other transfers it would not be expected to affect job choice.

\section{Estimation}

Section 2 shows that wage subsidies can lead to behavioral responses that alter job choice and job duration. Subsidies may, however, also have compositional effects. Since wage subsidies induce some individuals to start working, this, by itself, can lead to experimental control differences in wage growth and job duration. For example, if those induced to work by the earnings subsidy have below average job wage growth then this will result

\footnotetext{
${ }^{18}$ An exception to this statement is for jobs whose expected duration exceeds the subsidized period of three years. It can be shown that for these jobs, the subsidy makes the job with wage growth more attractive.

${ }^{19}$ Consider a person who is offered a 5 hour per week job at $\$ 10$ an hour and another job with the same hours that pays $\$ 9$ in the first month and $\$ 11$ in the following month. In the constant wage job, earnings are $\$ 200$ in both 4 -week months, so the individual receives full IA benefits. In the job with wage growth, earnings are $\$ 220$ in the second month, so IA benefits are reduced.
} 
in experimentals having lower wage growth than controls, even if the subsidy does not alter job choice .

As Ham and Lalonde (1996) shows, random assignment to the treatment and control groups does not eliminate the potential compositional effect. Consider the following simple model in which a randomly assigned treatment, $T$, is received during the experimental period. The effect of this treatment on latent employment, $M_{i}$, and wage growth, $\Delta W_{i}$, are given by

$$
\begin{aligned}
M_{i} & =\gamma_{0}+\gamma_{1} T_{i}+\varepsilon_{1_{i}} \\
\Delta W_{i} & =\alpha_{0}+\alpha_{1} T_{i}+\varepsilon_{2 i}
\end{aligned}
$$

where $M_{i}$ is a latent variable that reflects the propensity to be observed working in $t$ and $t-1$. $\Delta W_{i}$ is observed if $M_{i}>0 .{ }^{20}$ Random assignment ensures that $\varepsilon_{1 i}$ and $\varepsilon_{2 i}$ are independent of $T_{i}$. If wages were observable for all sample members in all periods, then one could obtain consistent estimates of $\alpha_{1}$, the behavioral effect of the treatment on wage growth, simply by comparing mean wages and wage growth of treatments and controls in the post-baseline period. Some sample members, however, do not work and for them we do not observe wage growth, which leads to the potential for the standard selection bias even with random assignment.

$$
E\left(\Delta W_{i} \mid M_{i}>0\right)=\alpha_{0}+\alpha_{1} T_{i}+E\left(\varepsilon_{2 i} \mid M_{i}>0\right) .
$$

As Ham and Lalonde (1996) points out, $E\left(\varepsilon_{2 i} \mid M_{i}>0\right) \neq 0$ even if $T_{i}$ is random unless $\varepsilon_{1 i}$ and $\varepsilon_{2 i}$ are statistically independent.

Since the SSP subsidy increases the effective wage, experimentals with low non-subsidized wages who would not have worked in the absence of the subsidy may be induced to work. This can lead to composition bias. Mean wages may decline among working experimentals because the randomly assigned experimentals include workers with low wages who find it advantageous to work because of the earnings subsidy. If these low wage workers who are induced to work also have non-random wage growth (i.e., $E\left(\varepsilon_{2 i} \mid M_{i}>0\right) \neq 0$ ), then their entry into the labor market will also affect the wage growth of experimentals. As a result there will be an experimental/control difference in wage growth even if there is no behavioral effect (i.e., $\alpha_{1}=0$ ).

The size of the compositional bias depends on the proportion of working experimentals who enter the labor market as a result of the subsidy. ${ }^{21}$ The wage change for this subset of experimentals reflects both a behavioral effect, $\alpha_{1}$, and a compositional effect, which we denote $\alpha_{c}{ }^{22}$ The change in wages for the balance of experimentals, who would have worked without the subsidy, is directly comparable to the change in the wages of working controls since both groups would have worked in the absence of the subsidy. For this group the experimental control difference reflects only a behavioral effect, $\alpha_{1}$. The expected value of the observed difference in wage growth for working experimentals and controls, $\hat{\alpha}_{1}$, is a mixture of experimental control difference for these two subsets of experimentals:

$$
\begin{aligned}
E\left(\hat{\alpha}_{1}\right) & =\pi \alpha_{1}+(1-\pi)\left(\alpha_{1}+\alpha_{c}\right) \\
& =\alpha_{1}+(1-\pi) \alpha_{c}
\end{aligned}
$$

\footnotetext{
${ }^{20}$ For notational simplictly, assume that both relationships are conditional on a set of observable covariates.

${ }^{21}$ This group is labeled the incentivised group by Card et al. (2001).

${ }^{22} \alpha_{c}=E\left(\varepsilon_{2 i} \mid M_{i}>0\right)$.
} 
where $\pi$ is the proportion of working experimentals who would have worked without the SSP subsidy. ${ }^{23}$

Equation 8 shows that the observed experimental control difference in wage growth is not an unbiased estimator of the behavioral effect, $\alpha_{1}$, and that the bias, $(1-\pi) \alpha_{c}$, goes to zero as either $\pi$ goes to one or $\alpha_{c}$ goes to zero. While $\alpha_{c}$ is not identifiable without further assumptions, $\pi$ can be estimated directly. Since $\pi$ is the proportion of experimentals who would have worked without the SSP subsidy it can be estimated directly by the employment probability of controls (who were not eligible for the subsidy) relative to experimentals. ${ }^{24}$ If both groups have the same employment probabilites then $\pi=1$ and there is no compositional effect.

Therefore, in order to determine the importance of the compositional effect we also estimate wage growth and job exit hazards for a subsample of experimentals whose employment probabilities are unlikely to have been affected by the earnings subsidy. Experimentals working at baseline constitute such a sample since they were already working without the subsidy. Since this sample selection is based on employment prior to random assignment, it does not reflect changes in employment induced by the program. Furthermore, we can test our identifying assumption that the post-baseline employment probability of these experimentals was not affected by the subsidy. If experimentals and controls working at baseline were not induced to work by the subsidy in the post-baseline period, then these experimentals and controls should have similar employment probabilities post-baseline. This is directly testable.

As we will show, this subset of controls and experimentals have nearly identical probabilities of working during the program period. This shows that $\pi$ is very close to one and that the compositional impact is near zero for this subsample. Estimates of experimental control differences in wage growth and hazards of changing jobs, therefore, primarily reflect behavioral impacts of the program for this subsample.

\section{Data}

The SSP data we use include wage and job histories for persons who were randomly assigned to the experimental and control groups. This randomization allows us to measure the differences in wage growth and turnover of the 2,827 individuals assigned to the IA control group and the 2,858 individuals assigned to the SSP experimental group. ${ }^{25}$ The SSP data include the key variables necessary to identify when respondents change jobs, as well as the wage changes both while working for the same employer and when moving to a new employer. ${ }^{26}$ We use information gathered from interviews at the time of random assignment (baseline) through the 54-month interview. ${ }^{27}$ During these interviews, respondents were

\footnotetext{
${ }^{23} \pi=\frac{1-F\left(-\gamma_{0}\right)}{1-F\left(-\gamma_{0}-\gamma_{1}\right)}$.

${ }^{24} \pi=\frac{\operatorname{Pr}(\text { Employed } \mid \text { Control })}{\operatorname{Pr}(\text { Employed } \mid \text { Expirimental })}$

${ }^{25}$ We exclude the $\mathrm{SSP}$-plus group, which received additional services.

${ }^{26}$ Since a substantial number of respondents held two or more jobs at the same time, we follow the primary job, which is defined as the job with the greatest number of hours worked in any given month.

${ }^{27}$ We only use observations up to 48 months after the baseline interview. This ensures that we observe job histories of SSP recipients as long as it is possible to receive the supplement while limiting the number
} 
asked questions about their jobs and earnings histories.

When examining wage growth, we are limited to the subsample of jobs that began after the 18th month of the survey since starting and ending wages were not recorded until after the 18-month interview. ${ }^{28}$ We are concerned about the generalizability of the results based on this sample; therefore, we explore whether this subsample gives results similar to the full sample when the outcomes are available for both. Specifically, we explore whether this sample restriction would have affected our conclusions about experimental/control differences in employment and job duration, which can be observed for the full sample. Appendix $\mathrm{B}$ provides results for the sample of individuals with jobs beginning after the 18-month interview. We show that this subsample used to estimate wage growth has similar baseline, employment and job duration characteristics as the full sample.

\section{Results}

In the following sections we provide contrasts between controls and two sets of experimentals. The first set includes all persons assigned to the experimental group, including experimentals who did not receive a supplement at any point. Contrast between the controls and all experimentals, including the group that did not take up the subsidy, gives the average treatment effect, where the treatment is interpreted as making a supplement available to a random group of welfare recipients. ${ }^{29}$ The average treatment effect is, therefore, a mixture of the effect on those who took up the supplement and those who did not.

The second set of experimentals includes only those who participated in the program, as evidenced by receiving the supplement. Since the decision to take up the subsidy is likely to be influenced by the expected benefits of the program, those who took up the program are likely to have higher expected gains from the program than a randomly chosen person who is offered the program. In terms used in the evaluation literature, comparing outcomes of controls with outcomes of experimentals who took up the program yields the impact of the treatment on the treated.

\subsection{Summary Statistics}

Table 1a shows the baseline characteristics of the 5,685 individuals in our full sample used to examine employment and job duration. Among the 2,858 experimentals, 1,888, or roughly two-thirds did not take up the subsidy. ${ }^{30}$ As can be seen in columns 2 and 3 , the

of observations observed after the supplement ends.

${ }^{28}$ We measure monthly within-job wage growth between the start of a job and the last observed month of the job.

${ }^{29}$ This interpretation assumes no compositional effects.

${ }^{30}$ Among those assigned to the experimental group, roughly two-thirds did not receive a subsidy because they either did not work full time within the first 12 months or they qualified but did not apply. Looking at the "no take up" group, however, shows that only four percent of those who were eligible yet did not take up the program worked full-time during the first twelve months. That is, the dominant reason for not taking up the program is not qualifying rather than qualifying but failing to apply for the program. The top three reasons for not taking up the program were that: the respondent could not find a job (32.7 percent); personal responsibilites interfered (15.2 percent); and health problems precluded full-time employment (14.0 percent). 
Table 1a

Summary Statistics at Baseline Interview

Full Sample

\begin{tabular}{|c|c|c|c|c|c|}
\hline & \multirow[b]{2}{*}{ All } & \multirow[b]{2}{*}{ Control (IA) } & \multicolumn{3}{|c|}{ Experimental } \\
\hline & & & SSP Eligible & Tookup SSP & $\begin{array}{c}\text { Did Not } \\
\text { Take Up } \\
\text { SSP } \\
\end{array}$ \\
\hline & (1) & (2) & (3) & (4) & (5) \\
\hline \multicolumn{6}{|l|}{ Demographic } \\
\hline Age & $\begin{array}{r}31.9 \\
(0.11)\end{array}$ & $\begin{array}{r}31.9 \\
(0.15)\end{array}$ & $\begin{array}{r}31.9 \\
(0.15)\end{array}$ & $\begin{array}{r}31.0 \\
(0.25)\end{array}$ & $\begin{array}{r}32.4 \\
(0.20)\end{array}$ \\
\hline Speaks English & $\begin{array}{r}0.97 \\
(0.00)\end{array}$ & $\begin{array}{r}0.97 \\
(0.00)\end{array}$ & $\begin{array}{r}0.97 \\
(0.00)\end{array}$ & $\begin{array}{r}0.99 \\
(0.00)\end{array}$ & $\begin{array}{r}0.96 \\
(0.00)\end{array}$ \\
\hline Speaks French & $\begin{array}{r}0.13 \\
(0.00)\end{array}$ & $\begin{array}{r}0.14 \\
(0.01)\end{array}$ & $\begin{array}{r}0.13 \\
(0.01)\end{array}$ & $\begin{array}{r}0.15 \\
(0.01)\end{array}$ & $\begin{array}{r}0.12 \\
(0.01)\end{array}$ \\
\hline Never Married & $\begin{array}{r}0.48 \\
(0.01)\end{array}$ & $\begin{array}{r}0.48 \\
(0.01)\end{array}$ & $\begin{array}{r}0.48 \\
(0.01)\end{array}$ & $\begin{array}{r}0.48 \\
(0.02)\end{array}$ & $\begin{array}{r}0.48 \\
(0.01)\end{array}$ \\
\hline Number of Kids & $\begin{array}{r}1.68 \\
(0.01)\end{array}$ & $\begin{array}{r}1.68 \\
(0.02)\end{array}$ & $\begin{array}{r}1.67 \\
(0.02)\end{array}$ & $\begin{array}{r}1.61 \\
(0.03)\end{array}$ & $\begin{array}{r}1.71 \\
(0.02)\end{array}$ \\
\hline Less Than High School & $\begin{array}{r}0.55 \\
(0.01)\end{array}$ & $\begin{array}{r}0.55 \\
(0.01)\end{array}$ & $\begin{array}{r}0.54 \\
(0.01)\end{array}$ & $\begin{array}{r}0.43 \\
(0.02)\end{array}$ & $\begin{array}{r}0.60 \\
(0.01)\end{array}$ \\
\hline High School Graduate & $\begin{array}{r}0.45 \\
(0.01)\end{array}$ & $\begin{array}{r}0.45 \\
(0.01)\end{array}$ & $\begin{array}{r}0.46 \\
(0.01)\end{array}$ & $\begin{array}{r}0.57 \\
(0.02)\end{array}$ & $\begin{array}{r}0.40 \\
(0.01)\end{array}$ \\
\hline \multicolumn{6}{|l|}{ Employment } \\
\hline Initial Experience (months) & $\begin{array}{c}88.92 \\
(1.05)\end{array}$ & $\begin{array}{c}89.93 \\
(1.48)\end{array}$ & $\begin{array}{l}87.91 \\
(1.48)\end{array}$ & $\begin{array}{r}102.42 \\
(2.58)\end{array}$ & $\begin{array}{r}80.50 \\
(1.79)\end{array}$ \\
\hline Employed & $\begin{array}{r}0.19 \\
(0.01)\end{array}$ & $\begin{array}{r}0.19 \\
(0.01)\end{array}$ & $\begin{array}{r}0.18 \\
(0.01)\end{array}$ & $\begin{array}{r}0.32 \\
(0.01)\end{array}$ & $\begin{array}{r}0.11 \\
(0.01)\end{array}$ \\
\hline Employed Full Time & $\begin{array}{r}0.07 \\
(0.00)\end{array}$ & $\begin{array}{r}0.07 \\
(0.00)\end{array}$ & $\begin{array}{r}0.06 \\
(0.00)\end{array}$ & $\begin{array}{r}0.13 \\
(0.01)\end{array}$ & $\begin{array}{r}0.02 \\
(0.00)\end{array}$ \\
\hline Employed Part Time & $\begin{array}{r}0.12 \\
(0.00)\end{array}$ & $\begin{array}{r}0.12 \\
(0.01)\end{array}$ & $\begin{array}{r}0.12 \\
(0.01)\end{array}$ & $\begin{array}{r}0.19 \\
(0.01)\end{array}$ & $\begin{array}{r}0.09 \\
(0.01)\end{array}$ \\
\hline No Previous Work Experience & $\begin{array}{r}0.05 \\
(0.00)\end{array}$ & $\begin{array}{r}0.06 \\
(0.00)\end{array}$ & $\begin{array}{r}0.05 \\
(0.00)\end{array}$ & $\begin{array}{r}0.01 \\
(0.00)\end{array}$ & $\begin{array}{r}0.07 \\
(0.01)\end{array}$ \\
\hline Not Employed and Not Looking & $\begin{array}{r}0.58 \\
(0.01)\end{array}$ & $\begin{array}{r}0.57 \\
(0.01)\end{array}$ & $\begin{array}{r}0.59 \\
(0.01)\end{array}$ & $\begin{array}{r}0.41 \\
(0.02)\end{array}$ & $\begin{array}{r}0.68 \\
(0.01)\end{array}$ \\
\hline \# Individuals & 5,685 & 2,827 & 2,858 & 970 & 1,888 \\
\hline
\end{tabular}

NOTE: Standard errors in parentheses. 
Table 1b

Summary Statistics at Baseline Interview

Employed at Baseline Interview

\begin{tabular}{|c|c|c|c|c|c|}
\hline & \multirow[b]{2}{*}{ All } & \multirow[b]{2}{*}{ Control (IA) } & \multicolumn{3}{|c|}{ Experimental } \\
\hline & & & SSP Eligible & Tookup SSP & $\begin{array}{c}\text { Did Not } \\
\text { Take Up } \\
\text { SSP }\end{array}$ \\
\hline & (1) & $(2)$ & (3) & (4) & (5) \\
\hline \multicolumn{6}{|l|}{ Demographic } \\
\hline Age & $\begin{array}{r}32.7 \\
(0.24)\end{array}$ & $\begin{array}{r}32.8 \\
(0.32)\end{array}$ & $\begin{array}{r}32.6 \\
(0.34)\end{array}$ & $\begin{array}{r}31.7 \\
(0.43)\end{array}$ & $\begin{array}{r}34.0 \\
(0.55)\end{array}$ \\
\hline Speaks English & $\begin{array}{r}0.99 \\
(0.00)\end{array}$ & $\begin{array}{r}0.99 \\
(0.00)\end{array}$ & $\begin{array}{r}0.99 \\
(0.00)\end{array}$ & $\begin{array}{r}0.99 \\
(0.01)\end{array}$ & $\begin{array}{r}1.00 \\
(0.00)\end{array}$ \\
\hline Speaks French & $\begin{array}{r}0.14 \\
(0.01)\end{array}$ & $\begin{array}{r}0.15 \\
(0.02)\end{array}$ & $\begin{array}{r}0.14 \\
(0.02)\end{array}$ & $\begin{array}{r}0.15 \\
(0.02)\end{array}$ & $\begin{array}{r}0.13 \\
(0.02)\end{array}$ \\
\hline Never Married & $\begin{array}{r}0.45 \\
(0.02)\end{array}$ & $\begin{array}{r}0.45 \\
(0.02)\end{array}$ & $\begin{array}{r}0.46 \\
(0.02)\end{array}$ & $\begin{array}{r}0.47 \\
(0.03)\end{array}$ & $\begin{array}{r}0.44 \\
(0.03)\end{array}$ \\
\hline Number of Kids & $\begin{array}{r}1.60 \\
(0.02)\end{array}$ & $\begin{array}{r}1.57 \\
(0.03)\end{array}$ & $\begin{array}{r}1.63 \\
(0.04)\end{array}$ & $\begin{array}{r}1.60 \\
(0.05)\end{array}$ & $\begin{array}{r}1.66 \\
(0.06)\end{array}$ \\
\hline Less Than High School & $\begin{array}{r}0.42 \\
(0.02)\end{array}$ & $\begin{array}{r}0.41 \\
(0.02)\end{array}$ & $\begin{array}{r}0.42 \\
(0.02)\end{array}$ & $\begin{array}{r}0.37 \\
(0.03)\end{array}$ & $\begin{array}{r}0.50 \\
(0.03)\end{array}$ \\
\hline High School Graduate & $\begin{array}{r}0.58 \\
(0.02)\end{array}$ & $\begin{array}{r}0.59 \\
(0.02)\end{array}$ & $\begin{array}{r}0.58 \\
(0.02)\end{array}$ & $\begin{array}{r}0.63 \\
(0.03)\end{array}$ & $\begin{array}{r}0.50 \\
(0.03)\end{array}$ \\
\hline \multicolumn{6}{|l|}{ Employment } \\
\hline Initial Experience (months) & $\begin{array}{r}121.25 \\
(2.41)\end{array}$ & $\begin{array}{r}122.73 \\
(3.40)\end{array}$ & $\begin{array}{r}119.70 \\
(3.42)\end{array}$ & $\begin{array}{r}121.10 \\
(4.55)\end{array}$ & $\begin{array}{r}117.72 \\
(5.16)\end{array}$ \\
\hline Employed Full Time & $\begin{array}{r}0.35 \\
(0.01)\end{array}$ & $\begin{array}{r}0.37 \\
(0.02)\end{array}$ & $\begin{array}{r}0.33 \\
(0.02)\end{array}$ & $\begin{array}{r}0.40 \\
(0.03)\end{array}$ & $\begin{array}{r}0.22 \\
(0.03)\end{array}$ \\
\hline Employed Part Time & $\begin{array}{r}0.65 \\
(0.01)\end{array}$ & $\begin{array}{r}0.63 \\
(0.02)\end{array}$ & $\begin{array}{r}0.67 \\
(0.02)\end{array}$ & $\begin{array}{r}0.60 \\
(0.03)\end{array}$ & $\begin{array}{r}0.78 \\
(0.03)\end{array}$ \\
\hline \# Individuals & 1,067 & 545 & 522 & 306 & 216 \\
\hline
\end{tabular}

NOTE: Standard errors in parentheses.

control and combined experimental groups (including those who took up the program and those who did not) closely resemble one another. For both groups, the women average just under 32 years of age and roughly 14 percent speak French. Almost 50 percent have never married, and they have an average of 1.7 children. Both experimentals and controls have low education, with roughly 55 percent having less than a high school degree. Both groups had some previous labor market experience. The average months of previous experience for experimentals and controls is just under 90 months. This indicates that these females had more than seven years of experience at the baseline. Eighteen percent of SSP eligibles were employed at baseline, which is nearly identical to the 19 percent of controls.

The summary statistics in Table 1a indicate that the experimental and control groups in our full sample are similar on the basis of observed demographic and labor market characteristics, including the proportion working at baseline

Table $1 \mathrm{~b}$ show that the same patterns hold for our sub-sample of persons working at 
baseline who are less likely to be affected by compositional effects of the subsidy. Not surprisingly, these experimentals and controls have more previous labor market experience than the full sample.

While experimentals resemble controls, there are striking differences between those experimentals who took up the program and those who did not. Table 1a shows that experimentals who took up the program (column 4), had substantially more attachment to the labor market than those who did not take up the program (column 5). Table 1a shows that those who took up the program had 102 months of prior work experience at the baseline survey compared to 81 months for those experimentals who did not take up the program. Likewise, the proportion working at the baseline interview is 32 percent for the take up group, but only 11 percent for those who did not take up the benefits despite being eligible.

Since wage information is available only for a subset of respondents, we also show baseline characteristics for these groups in Tables B1a and B1b of Appendix B. These summary statistics show that limiting the sample to experimentals and controls with valid wage does not alter the patterns found for the full sample.

\subsection{Differences in Employment}

We continue by confirming that our full sample shows the same positive employment effects of earnings subsidies found in previous studies. ${ }^{31}$ Table 2 a shows the number of months experimentals and controls were observed working after the baseline survey. Again, these summary statistics are shown for controls and experimentals (who are further disaggregated into those who took up the program and those who did not). These data show that, consistent with previous studies, the SSP supplement increased the probability that former welfare recipients would take full-time jobs. The top panel of Table 2a shows that for control group members in the full sample the average number of months of work through the 54 -month follow-up period is 11.7 months. The following panel shows that roughly half of this is full-time work (6.9 months). Experimentals, however, worked substantially more and the difference largely reflects an increase in full-time work. For the experimental group, the average number of months worked is 14.1 months and roughly two-thirds of that is full-time work (10.1 months). This indicates that the program increased the average number of months worked by 3.4 and almost all of this reflects an increase in full-time work. Not unexpectedly, experimentals who took up the program show substantially larger increases in work.

Table $2 \mathrm{~b}$ shows the same measures for our sub-sample of persons working at baseline. Our prior expectations are that post-baseline employment for these experimentals and controls will be similar since both groups were already working even before the subsidy was offered. If the subsidy does not increase the probability of work for experimentals then $\pi$ is close to one and there is no compositional bias for this sub-sample.

Table $2 \mathrm{~b}$ shows that controls worked an average of 28.0 months while experimentals worked 28.9 months. $^{32}$ This implies that $\pi=.97$ for this subsample. Therefore, changes

\footnotetext{
${ }^{31}$ See Michalopoulos et al. (2002).

${ }^{32}$ Tables B2a and B2b in Appendix B show the same measures for the sample of workers with jobs that began after the 18-month interview for the full sample and for those employed at the baseline interview, respectively. These subsamples are used in Section 5.4 to compare the wage growth of experimentals and controls. Patterns found in the subsample are similar to those found in Tables 2a and 2b.
} 
Table 2a

Observed Employment

Full Sample

\begin{tabular}{|c|c|c|c|c|c|}
\hline & \multirow[b]{2}{*}{ All } & \multirow[b]{2}{*}{ Control (IA) } & \multicolumn{3}{|c|}{ Experimental } \\
\hline & & & SSP Eligible & Tookup SSP & $\begin{array}{c}\text { Did Not Take } \\
\text { Up SSP }\end{array}$ \\
\hline & (1) & (2) & (3) & (4) & $(5)$ \\
\hline \multicolumn{6}{|l|}{ All Jobs } \\
\hline Average Employment (months) & $\begin{array}{r}12.89 \\
(0.19)\end{array}$ & $\begin{array}{l}11.66 \\
(0.26)\end{array}$ & $\begin{array}{r}14.11 \\
(0.27)\end{array}$ & $\begin{array}{l}26.84 \\
(0.39)\end{array}$ & $\begin{array}{r}7.58 \\
(0.26)\end{array}$ \\
\hline $\begin{array}{l}\text { Average Number of Jobs per } \\
\text { Worker }\end{array}$ & $\begin{array}{r}1.90 \\
(0.02)\end{array}$ & $\begin{array}{r}1.82 \\
(0.03)\end{array}$ & $\begin{array}{r}1.97 \\
(0.03)\end{array}$ & $\begin{array}{r}2.37 \\
(0.04)\end{array}$ & $\begin{array}{r}1.60 \\
(0.03)\end{array}$ \\
\hline \multicolumn{6}{|l|}{ Full-time Jobs } \\
\hline Average Employment (months) & $\begin{array}{r}8.51 \\
(0.17)\end{array}$ & $\begin{array}{r}6.89 \\
(0.21)\end{array}$ & $\begin{array}{r}10.12 \\
(0.25)\end{array}$ & $\begin{array}{l}23.38 \\
(0.43)\end{array}$ & $\begin{array}{r}3.30 \\
(0.17)\end{array}$ \\
\hline $\begin{array}{l}\text { Average Number of Jobs per } \\
\text { Worker }\end{array}$ & $\begin{array}{r}1.64 \\
(0.02)\end{array}$ & $\begin{array}{r}1.55 \\
(0.03)\end{array}$ & $\begin{array}{r}1.71 \\
(0.03)\end{array}$ & $\begin{array}{r}1.93 \\
(0.04)\end{array}$ & $\begin{array}{r}1.35 \\
(0.03)\end{array}$ \\
\hline \multicolumn{6}{|l|}{ Part-time Jobs } \\
\hline Average Employment (months) & $\begin{array}{r}5.76 \\
(0.14)\end{array}$ & $\begin{array}{r}6.16 \\
(0.20)\end{array}$ & $\begin{array}{r}5.37 \\
(0.18)\end{array}$ & $\begin{array}{r}5.48 \\
(0.29)\end{array}$ & $\begin{array}{r}5.31 \\
(0.23)\end{array}$ \\
\hline $\begin{array}{l}\text { Average Number of Jobs per } \\
\text { Worker }\end{array}$ & $\begin{array}{r}1.39 \\
(0.01)\end{array}$ & $\begin{array}{r}1.39 \\
(0.02)\end{array}$ & $\begin{array}{r}1.39 \\
(0.02)\end{array}$ & $\begin{array}{r}1.47 \\
(0.04)\end{array}$ & $\begin{array}{r}1.35 \\
(0.03)\end{array}$ \\
\hline $\begin{array}{l}\text { \# Individuals } \\
\text { \# Jobs } \\
\text { \# Full-time Jobs } \\
\text { \# Part-time Jobs }\end{array}$ & $\begin{array}{l}5,685 \\
6,793 \\
3,833 \\
2,968\end{array}$ & $\begin{array}{l}2,827 \\
3,069 \\
1,576 \\
1,495\end{array}$ & $\begin{array}{l}2,858 \\
3,724 \\
2,257 \\
1,473\end{array}$ & $\begin{array}{r}970 \\
2,198 \\
1,627 \\
572\end{array}$ & $\begin{array}{r}1,888 \\
1,526 \\
630 \\
901\end{array}$ \\
\hline
\end{tabular}

NOTE: Standard errors in parentheses.

Table 2b

Observed Employment Employed at Baseline Interview

\begin{tabular}{|c|c|c|c|c|c|}
\hline & \multirow[b]{2}{*}{ All } & \multirow[b]{2}{*}{ Control (IA) } & \multicolumn{3}{|c|}{ Experimental } \\
\hline & & & SSP Eligible & Tookup SSP & $\begin{array}{c}\text { Did Not Take } \\
\text { Up SSP }\end{array}$ \\
\hline & (1) & (2) & (3) & (4) & $(5)$ \\
\hline \multicolumn{6}{|l|}{ All Jobs } \\
\hline Average Employment (months) & $\begin{array}{r}28.47 \\
(0.41)\end{array}$ & $\begin{array}{l}28.01 \\
(0.57)\end{array}$ & $\begin{array}{r}28.95 \\
(0.57)\end{array}$ & $\begin{array}{r}33.15 \\
(0.59)\end{array}$ & $\begin{array}{r}22.99 \\
(0.97)\end{array}$ \\
\hline $\begin{array}{l}\text { Average Number of Jobs per } \\
\text { Worker }\end{array}$ & $\begin{array}{r}2.22 \\
(0.04)\end{array}$ & $\begin{array}{r}2.10 \\
(0.05)\end{array}$ & $\begin{array}{r}2.34 \\
(0.06)\end{array}$ & $\begin{array}{r}2.60 \\
(0.08)\end{array}$ & $\begin{array}{r}1.98 \\
(0.09)\end{array}$ \\
\hline \multicolumn{6}{|l|}{ Full-time Jobs } \\
\hline Average Employment (months) & $\begin{array}{l}17.19 \\
(0.49)\end{array}$ & $\begin{array}{l}15.57 \\
(0.67)\end{array}$ & $\begin{array}{r}18.89 \\
(0.71)\end{array}$ & $\begin{array}{l}26.79 \\
(0.82)\end{array}$ & $\begin{array}{r}7.69 \\
(0.77)\end{array}$ \\
\hline $\begin{array}{l}\text { Average Number of Jobs per } \\
\text { Worker }\end{array}$ & $\begin{array}{r}1.79 \\
(0.04)\end{array}$ & $\begin{array}{r}1.70 \\
(0.05)\end{array}$ & $\begin{array}{r}1.87 \\
(0.06)\end{array}$ & $\begin{array}{r}2.02 \\
(0.07)\end{array}$ & $\begin{array}{r}1.48 \\
(0.08)\end{array}$ \\
\hline \multicolumn{6}{|l|}{ Part-time Jobs } \\
\hline Average Employment (months) & $\begin{array}{r}13.39 \\
(0.46)\end{array}$ & $\begin{array}{r}14.50 \\
(0.66)\end{array}$ & $\begin{array}{r}12.23 \\
(0.63)\end{array}$ & $\begin{array}{r}8.79 \\
(0.68)\end{array}$ & $\begin{array}{r}17.11 \\
(1.09)\end{array}$ \\
\hline $\begin{array}{l}\text { Average Number of Jobs per } \\
\text { Worker }\end{array}$ & $\begin{array}{r}1.52 \\
(0.03)\end{array}$ & $\begin{array}{r}1.51 \\
(0.04)\end{array}$ & $\begin{array}{r}1.54 \\
(0.04)\end{array}$ & $\begin{array}{r}1.48 \\
(0.05)\end{array}$ & $\begin{array}{r}1.60 \\
(0.07)\end{array}$ \\
\hline $\begin{array}{l}\text { \# Individuals } \\
\text { \# Jobs } \\
\text { \# Full-time Jobs } \\
\text { \# Part-time Jobs }\end{array}$ & $\begin{array}{l}1,067 \\
2,264 \\
1,163 \\
1,103\end{array}$ & $\begin{array}{r}545 \\
1,101 \\
541 \\
560\end{array}$ & $\begin{array}{r}522 \\
1,163 \\
622 \\
543\end{array}$ & $\begin{array}{l}306 \\
766 \\
485 \\
281\end{array}$ & $\begin{array}{l}216 \\
397 \\
137 \\
262\end{array}$ \\
\hline
\end{tabular}

NOTE: Standard errors in parentheses. 
in labor market outcomes for this sub-sample largely reflect behavioral, not compositional effects. For example, the higher propensity for these experimentals to work full-time can be attributed to behavioral responses to the program since the average number of full-time months for experimentals is not being driven up by new labor market participants with above average propensity to work full-time.

\subsection{Differences in Job Duration}

Our analytical model predicts that experimentals are more likely to search on the job than are controls and that they will change jobs more often. The former is a direct consequence of the fact that the opportunity cost of searching while not employed is higher for experimentals than for controls since experimentals forego the earnings subsidy when they search while not employed. The result of accepting some lower-paying jobs in order to search while working leads to a higher probability that the current wage will be dominated by a new wage offer. This would lead to shorter job duration. ${ }^{33}$

Proportional hazard models of the competing risk of exiting the current job to move directly to another job or exiting to non-employment are shown in Tables $3 \mathrm{a}$ and $3 \mathrm{~b}$. Since experimental/control differences may reflect compositional as well as behavioral effects, Tables $3 \mathrm{a}$ and $3 \mathrm{~b}$ present estimates for the full sample and for the sample of persons working at baseline. In both tables, columns 3 and 4 present coefficient estimates for exits directly to other jobs. Columns 5 and 6 show coefficients for exits to non-employment.

Column 3 of Table 3 a shows that the odds ratio of leaving a job to move directly to another job is 25 percent higher for experimentals than controls and this difference is significant at conventional levels. When the contrast is between controls and experimentals who took up the program (column 4), the coefficient nearly doubles to 0.40 indicating that the experimentals who took up the program were much more likely than controls to leave their current jobs to take other jobs. These two columns, therefore, support the prediction that workers who receive SSP have higher job turnover than IA recipients.

While the results in Table 3a could be driven by higher job turnover among those induced to work by the program, the differences in job turnover between experimentals and controls are largely unchanged when the subsample is restricted to those working at baseline (see Table $3 \mathrm{~b}$ ). This indicates that the differences in job transitions are not driven by compositional effects.

The Burdett (1978) model of on-the-job search implies that individuals will not quit voluntarily to search while unemployed. Voluntary quits may occur, however, for other reasons, such as increased family obligations or geographic relocation. The availability of a subsidy will, however, increase the foregone earnings if the person quits, which implies that experimentals are less likely to make such transitions. Columns 5 and 6 of Tables $3 \mathrm{a}$ and $3 \mathrm{~b}$ are consistent with this prediction since the hazard of exiting to non-employment is lower for experimentals than controls. ${ }^{34}$

\footnotetext{
${ }^{33} \mathrm{An}$ indirect implication is that experimentals accepted lower wages than controls in their first jobs after the program is started. While we do not have starting wages for jobs that ended before the 18th month interview, we do have the mean wage in the first job. Mean wages in the first jobs of experimentals were 13 percent lower than for controls, which is a statistically significant difference.

${ }^{34}$ Tables B3a and B3b mirror Tables 3a and 3b for the sample with jobs observed starting after the 18 th
} 
Table 3a

Cox Proportional Hazard Model of Job Duration Full Sample

\begin{tabular}{|c|c|c|c|c|c|c|}
\hline \multirow{3}{*}{ Control versus: } & \multicolumn{2}{|c|}{ All Job Exits } & \multicolumn{2}{|c|}{$\underline{\text { Job-to-Job Exits }}$} & \multicolumn{2}{|c|}{ Job-to-Unemployment Exits } \\
\hline & SSP & Take Up & SSP & Take Up & SSP & Take Up \\
\hline & (1) & (2) & (3) & (4) & (5) & (6) \\
\hline In SSP Group & $\begin{array}{r}0.004 \\
(0.036)\end{array}$ & $\begin{array}{c}-0.055 \\
(0.040)\end{array}$ & $\begin{array}{l}0.249^{* * * *} \\
(0.066)\end{array}$ & $\begin{array}{l}0.402^{* * * *} \\
(0.069)\end{array}$ & $\begin{array}{l}-0.088^{* *} \\
(0.044)\end{array}$ & $\begin{array}{l}-0.2611^{* * * *} \\
(0.051)\end{array}$ \\
\hline Female & $\begin{array}{r}0.094 \\
(0.095)\end{array}$ & $\begin{array}{r}0.054 \\
(0.105)\end{array}$ & $\begin{array}{r}0.020 \\
(0.167)\end{array}$ & $\begin{array}{r}-0.080 \\
(0.172)\end{array}$ & $\begin{array}{r}0.126 \\
(0.118)\end{array}$ & $\begin{array}{r}0.123 \\
(0.136)\end{array}$ \\
\hline Speaks French & $\begin{array}{r}0.065 \\
(0.048)\end{array}$ & $\begin{array}{r}0.054 \\
(0.054)\end{array}$ & $\begin{array}{l}0.228^{* * * *} \\
(0.082)\end{array}$ & $\begin{array}{l}0.202^{* *} \\
(0.088)\end{array}$ & $\begin{array}{r}-0.007 \\
(0.061)\end{array}$ & $\begin{array}{r}-0.023 \\
(0.069)\end{array}$ \\
\hline Never Married & $\begin{array}{l}0.124^{* * *} \\
(0.037)\end{array}$ & $\begin{array}{l}0.130 \\
(0.042)\end{array}$ & $\begin{array}{r}0.043 \\
(0.067)\end{array}$ & $\begin{array}{r}0.055 \\
(0.072)\end{array}$ & $\begin{array}{l}0.154^{* * * *} \\
(0.046)\end{array}$ & $\begin{array}{c}0.1700^{* * * *} \\
(0.053)\end{array}$ \\
\hline Number of Children & $\begin{array}{r}0.021 \\
(0.023)\end{array}$ & $\begin{array}{r}0.019 \\
(0.027)\end{array}$ & $\begin{array}{l}-0.100 \text { ** } \\
(0.044)\end{array}$ & $\begin{array}{r}-0.069 \\
(0.048)\end{array}$ & $\begin{array}{c}0.058^{* *} \\
(0.028)\end{array}$ & $\begin{array}{r}0.048 \\
(0.033)\end{array}$ \\
\hline High School Graduate & $\begin{array}{c}-0.070 \\
(0.036)\end{array}$ & $\begin{array}{l}-0.081 \\
(0.041)\end{array}$ & $\begin{array}{l}0.167^{* *} \\
(0.066)\end{array}$ & $\begin{array}{c}0.155^{\text {** }} \\
(0.072)\end{array}$ & $\begin{array}{l}-0.183^{* * *} \\
(0.044)\end{array}$ & $\begin{array}{l}-0.209^{* * *} \\
(0.051)\end{array}$ \\
\hline $\begin{array}{l}\text { \# Exits } \\
\text { Control } \\
\text { Experimental }\end{array}$ & & & & & & \\
\hline
\end{tabular}

NOTES:

(1) Standard errors in parentheses.

(2) Coefficient estimates are significant at the $10 \%(*), 5 \%(* *)$, or $1 \%(* * *)$ levels.

Table $3 b$

Cox Proportional Hazard Model of Job Duration Employed at Baseline Interview

\begin{tabular}{|c|c|c|c|c|c|c|}
\hline \multirow{3}{*}{ Control versus: } & \multicolumn{2}{|c|}{ All Job Exits } & \multicolumn{2}{|c|}{$\underline{\text { Job-to-Job Exits }}$} & \multicolumn{2}{|c|}{ Job-to-Unemployment Exits } \\
\hline & SSP & Take Up & SSP & Take Up & SSP & Take Up \\
\hline & $(\mathbf{1})$ & (2) & (3) & (4) & $(5)$ & (6) \\
\hline In SSP Group & $\begin{array}{r}0.049 \\
(0.070)\end{array}$ & $\begin{array}{r}0.016 \\
(0.077)\end{array}$ & $\begin{array}{l}0.3311^{* * * *} \\
(0.113)\end{array}$ & $\begin{array}{l}0.452^{* * * *} \\
(0.119)\end{array}$ & $\begin{array}{r}-0.129 \\
(0.091)\end{array}$ & $\begin{array}{l}-0.308^{* * * *} \\
(0.107)\end{array}$ \\
\hline Female & $\begin{array}{r}-0.095 \\
(0.192)\end{array}$ & $\begin{array}{r}-0.166 \\
(0.212)\end{array}$ & $\begin{array}{r}-0.029 \\
(0.326)\end{array}$ & $\begin{array}{r}-0.248 \\
(0.330)\end{array}$ & $\begin{array}{r}-0.200 \\
(0.239)\end{array}$ & $\begin{array}{r}-0.186 \\
(0.278)\end{array}$ \\
\hline Speaks French & $\begin{array}{r}-0.089 \\
(0.100)\end{array}$ & $\begin{array}{l}-0.063 \\
(0.108)\end{array}$ & $\begin{array}{r}0.074 \\
(0.150)\end{array}$ & $\begin{array}{r}0.108 \\
(0.157)\end{array}$ & $\begin{array}{r}-0.172 \\
(0.134)\end{array}$ & $\begin{array}{r}-0.169 \\
(0.149)\end{array}$ \\
\hline Never Married & $\begin{array}{c}0.127^{*} \\
(0.073)\end{array}$ & $\begin{array}{c}0.157^{* *} \\
(0.080)\end{array}$ & $\begin{array}{r}0.178 \\
(0.117)\end{array}$ & $\begin{array}{r}0.154 \\
(0.125)\end{array}$ & $\begin{array}{r}0.069 \\
(0.096)\end{array}$ & $\begin{array}{r}0.133 \\
(0.107)\end{array}$ \\
\hline Number of Children & $\begin{array}{r}-0.004 \\
(0.045)\end{array}$ & $\begin{array}{r}0.016 \\
(0.050)\end{array}$ & $\begin{array}{r}-0.031 \\
(0.074)\end{array}$ & $\begin{array}{r}-0.017 \\
(0.079)\end{array}$ & $\begin{array}{r}-0.011 \\
(0.059)\end{array}$ & $\begin{array}{r}0.019 \\
(0.066)\end{array}$ \\
\hline High School Graduate & $\begin{array}{r}0.045 \\
(0.073)\end{array}$ & $\begin{array}{r}0.008 \\
(0.081)\end{array}$ & $\begin{array}{r}0.165 \\
(0.119)\end{array}$ & $\begin{array}{r}0.097 \\
(0.127)\end{array}$ & $\begin{array}{r}-0.040 \\
(0.095)\end{array}$ & $\begin{array}{r}-0.058 \\
(0.107)\end{array}$ \\
\hline $\begin{array}{l}\text { \# Exits } \\
\quad \text { Control } \\
\text { Experimental }\end{array}$ & & & & & & \\
\hline
\end{tabular}

NOTES:

(1) Standard errors in parentheses.

(2) Coefficient estimates are significant at the $10 \%(*), 5 \%(* *)$, or $1 \%(* * *)$ levels. 


\subsection{Differences in Wage Growth}

In Section 2.1 we showed that the behavioral effect on within-job wage growth depends on the functional form of the wage subsidy or transfer system. If a person is indifferent between two jobs in the absence of transfers, then under a post-transfer wage that is a concave function of the pre-subsidy wage, she would prefer the job with lower wage growth. If, however, the subsidy was linear, she would remain indifferent between the two jobs.

While the SSP subsidy is linear in its effective range, the IA transfer system strongly discourages taking jobs with high wage growth since the wage gains are subject to a 100 percent marginal tax rate above monthly earnings of $\$ 200$. This implies that experimentals who are eligible for the SSP subsidy would have higher within-job wage growth than the controls, who are only eligible for the IA transfer. The SSP subsidy may also affect between-job wage growth, though the effect of the subsidy depends on the functional form of the wage offer distribution. Since we have no priors on the functional form of this distribution, the effect of the subsidy on between-job wage growth remains an empirical question.

Tables $4 \mathrm{a}$ and $4 \mathrm{~b}$ show mean within- and between-job wage growth for the full sample and those working at baseline. ${ }^{35}$ The top panel of each table shows monthly within-job wage growth. The point estimate of the mean monthly wage growth for experimentals in Table $4 \mathrm{a}$ is .0125, which is considerably higher than the .0092 for controls and the difference is statistically significant. Similar patterns are shown in Table $4 \mathrm{~b}$, which includes only persons working at the baseline interview. Within-job wage growth is .0106 for experimentals and .0066 for control group members who had already demonstrated the willingness to work before the program was instituted. The experimental/control difference is even larger for this subset than for the full sample, though the difference is no longer statistically significant due to the smaller sample size.

While the analytical model does not have strong predictions on the effects of the earnings subsidy on between-job wage growth, the bottom panel of Tables $4 \mathrm{a}$ and $4 \mathrm{~b}$ indicate that the experimentals have a statistically significant gain of 7.0 percent when transitioning directly from one job to the next, and that the difference with controls is statistically significant. Not surprisingly, experimentals have smaller growth in wages than controls when there is an intervening spell of non-employment since they forego the subsidy as well as the wage while unemployed, though the experimental/control difference is not significant. The fact that Table $4 \mathrm{~b}$ gives results similar to Table $4 \mathrm{a}$ indicates that these patterns are still present when focusing on a subsample for whom the compositional effects are expected to be small.

\section{Conclusions}

We started this paper by asking whether wage or earnings supplements can affect job choice and job duration. The answer to this question is of particular interest given the recent focus in Canada and the U.S. on earnings supplements as a method of income support. If

month. While the coefficients for the smaller sample are generally slightly smaller, the patterns are similar.

${ }^{35}$ As discussed earlier, wage growth is available only for jobs that started after the 18-month interview. Appendix B, however, shows that this subsample does not differ substantively from the full sample on measures common to both. 
Table 4a

Mean Monthly Log Wage Growth

Full Sample

JOBS STARTED AFTER 18TH MONTH

\begin{tabular}{|c|c|c|c|c|c|}
\hline & \multirow[b]{2}{*}{ All } & \multirow[b]{2}{*}{ Control (IA) } & \multicolumn{3}{|c|}{ Experimental } \\
\hline & & & SSP Eligible & $\begin{array}{l}\text { Took up } \\
\text { SSP }\end{array}$ & $\begin{array}{c}\text { Did Not } \\
\text { Take Up } \\
\text { SSP }\end{array}$ \\
\hline & (1) & (2) & \begin{tabular}{|l|} 
(3) \\
\end{tabular} & (4) & (5) \\
\hline \multicolumn{6}{|l|}{ Within-job Wage Changes } \\
\hline Within-job Wage Change & $\begin{array}{l}0.0109 \\
(0.002)\end{array}$ & $\begin{array}{l}0.0092 \\
(0.002)\end{array}$ & $\begin{array}{l}0.0125 \\
(0.002)\end{array}$ & $\begin{array}{l}0.0152 \\
(0.004)\end{array}$ & $\begin{array}{l}0.0095 \\
(0.003)\end{array}$ \\
\hline \multicolumn{6}{|l|}{ Between-job Wage Changes } \\
\hline All Between-job Wage Change & $\begin{array}{l}0.0237 \\
(0.013)\end{array}$ & $\begin{array}{l}0.0229 \\
(0.022)\end{array}$ & $\begin{array}{l}0.0244 \\
(0.016)\end{array}$ & $\begin{array}{l}0.0277 \\
(0.014)\end{array}$ & $\begin{array}{l}0.0164 \\
(0.042)\end{array}$ \\
\hline Job-to-Job Exits & $\begin{array}{l}0.0366 \\
(0.019)\end{array}$ & $\begin{array}{c}-0.0144 \\
(0.038)\end{array}$ & $\begin{array}{l}0.0696 \\
(0.020)\end{array}$ & $\begin{array}{l}0.0828 \\
(0.022)\end{array}$ & $\begin{array}{l}0.0191 \\
(0.045)\end{array}$ \\
\hline Intervening Spell of Non-employment & $\begin{array}{l}0.0123 \\
(0.017)\end{array}$ & $\begin{array}{l}0.0343 \\
(0.029)\end{array}$ & $\begin{array}{l}-0.0057 \\
(0.020)\end{array}$ & $\begin{array}{c}-0.0214 \\
(0.018)\end{array}$ & $\begin{array}{l}0.0253 \\
(0.046)\end{array}$ \\
\hline
\end{tabular}

NOTE: Standard errors in parentheses.

Table $4 \mathrm{~b}$

Mean Monthly Log Wage Growth

Employed at Baseline Interview

JOBS STARTED AFTER 18TH MONTH

\begin{tabular}{|c|c|c|c|c|c|}
\hline & \multirow[b]{2}{*}{ All } & \multirow[b]{2}{*}{ Control (IA) } & \multicolumn{3}{|c|}{ Experimental } \\
\hline & & & SSP Eligible & $\begin{array}{c}\text { Took up } \\
\text { SSP }\end{array}$ & $\begin{array}{c}\text { Did Not } \\
\text { Take Up } \\
\text { SSP } \\
\end{array}$ \\
\hline & (1) & \begin{tabular}{|l|}
$(2)$ \\
\end{tabular} & \begin{tabular}{|l|} 
(3) \\
\end{tabular} & (4) & (5) \\
\hline \multicolumn{6}{|l|}{ Within-job Wage Changes } \\
\hline Within-job Wage Change & $\begin{array}{l}0.0086 \\
(0.004)\end{array}$ & $\begin{array}{l}0.0066 \\
(0.005)\end{array}$ & $\begin{array}{l}0.0106 \\
(0.006)\end{array}$ & $\begin{array}{l}0.0170 \\
(0.007)\end{array}$ & $\begin{array}{r}-0.0084 \\
(0.007)\end{array}$ \\
\hline \multicolumn{6}{|l|}{ Between-job Wage Changes } \\
\hline All Between-job Wage Change & $\begin{array}{l}0.0404 \\
(0.026)\end{array}$ & $\begin{array}{l}0.0508 \\
(0.044)\end{array}$ & $\begin{array}{l}0.0302 \\
(0.030)\end{array}$ & $\begin{array}{l}0.0127 \\
(0.029)\end{array}$ & $\begin{array}{l}0.1295 \\
(0.115)\end{array}$ \\
\hline Job-to-Job Exits & $\begin{array}{l}0.0693 \\
(0.028)\end{array}$ & $\begin{array}{l}0.0469 \\
(0.032)\end{array}$ & $\begin{array}{l}0.0861 \\
(0.043)\end{array}$ & $\begin{array}{l}0.0770 \\
(0.044)\end{array}$ & $\begin{array}{l}0.2779 \\
(0.106)\end{array}$ \\
\hline Intervening Spell of Non-employment & $\begin{array}{l}0.0184 \\
(0.043)\end{array}$ & $\begin{array}{l}0.0477 \\
(0.070)\end{array}$ & $\begin{array}{l}-0.0165 \\
(0.045)\end{array}$ & $\begin{array}{l}-0.0511 \\
(0.031)\end{array}$ & $\begin{array}{l}0.0943 \\
(0.154)\end{array}$ \\
\hline
\end{tabular}

NOTE: Standard errors in parentheses. 
earnings supplements can increase wage growth as well as employment, then these programs have dual benefits.

Our analytical framework indicates that there are sound economic reasons to believe that a wage or earnings subsidy can affect the type of job a person accepts and the length of time the person stays in a job. Subsidies are predicted to induce individuals to accept offers and to search for better jobs while employed, since the opportunity cost of searching while unemployed is increased by the foregone subsidy. If individuals initially accept jobs with lower wages in order to get the subsidy, they are more likely to find new jobs that dominate the initial jobs they accepted. This leads to shorter expected job durations. Whether this makes jobs with lower starting wages but higher wage growth more attractive than jobs with flatter wage profiles depends on the structure of the subsidy. Wage or earnings subsidies can also affect between-job wage growth, but the sign of the effect depends on the form of the wage offer distribution.

Our empirical work shows that experimentals in the SSP have shorter job durations and are more likely to move directly to other jobs than are controls. Experimentals are, however, less likely to leave their jobs and become unemployed. The jobs accepted by experimentals have higher within-job wage growth than the jobs accepted by controls. This is reinforced by higher between-job wage growth for experimentals. These patterns are consistent with the behavioral predictions of the analytical framework.

While these patterns could also be the result of compositional effects of the program, we find similar results for a sub-sample already working at baseline. Since the post-baseline employment rates for these experimentals and controls are nearly identical we conclude that changes in their behavior do not reflect compositional effects. 


\section{A Impact of Subsidy on Within-job Wage Growth}

In this appendix we derive the relationship between the form of the subsidy and its effect on the choice of jobs. Consider the choice between job A, which has a wage profile given by $w(t)=w_{A}(t)$, and job $\mathrm{B}$, which pays a constant wage, $w(t)=w_{B}$, over the same $T$ periods. ${ }^{36}$ The constant wage, $\widetilde{w}_{A}$, that produces an expected wage stream equal to that of job A satisfies the following condition:

$$
T \widetilde{w}_{A}=\int^{T} w_{A}(t) d t \equiv W_{A}(T) .
$$

Solving for the constant-wage equivalent to job A yields the threshold value:

$$
\widetilde{w}_{A}=\frac{W_{A}(T)}{T} \cdot 37
$$

An income-maximizing worker would choose job $\mathrm{B}$ over job $\mathrm{A}$ only if the constant wage in job $\mathrm{B}$ exceeds the constant wage equivalent of job $\mathrm{A}\left(w_{B}<\widetilde{w}_{A}\right)$.

To see the effect of an earnings supplement on the choice between jobs, let the wages of both job A and job B be supplemented according to the function $s(w(t))$, which maps pre-subsidy wages, $w(t)$, into post-subsidy wages, $w^{s}(t)=s(w(t))$. We then ask if the supplement raises or lowers the constant wage equivalent of job A. If the subsidy changes the threshold that separates acceptable from unacceptable constant-wage jobs, then the availability of the supplement affects the choice of jobs.

Similar to equation (A2), the constant wage equivalent to the supplemented stream of wages from job $\mathrm{A}$ is given by:

$$
\widetilde{w}_{A}^{s}=\frac{W_{A}^{s}(T)}{T},
$$

where:

$$
W_{A}^{s}(T)=\int^{T} w_{A}^{s}(t) d t
$$

In order to see the impact of the supplement on job choice, we compare the constantwage equivalent of the subsidized job $\mathrm{A}, \widetilde{w}_{A}^{s}$, to the subsidized value of the constant-wage equivalent for job A, $s\left(\widetilde{w}_{A}\right)$. If the subsidy is such that $\widetilde{w}_{A}^{s}=s\left(\widetilde{w}_{A}\right)$, then the subsidy has no effect on the choice between job $\mathrm{A}$ and job $\mathrm{B}$ since the relative threshold does not change. If, however, $\widetilde{w}_{A}^{s}>s\left(\widetilde{w}_{A}\right)$, then the supplement raises the constant wage equivalent threshold and the person is more likely to accept a job with wage growth (job A) when the supplement is available.

Since $\widetilde{w}_{A}$ is the mean of $w_{A}(t)$, comparing $s\left(\widetilde{w}_{A}\right)$ with $\widetilde{w}_{A}^{s}$ requires that we compare the transformation of a mean with the mean of the transformed variable, $\widetilde{w}_{A}^{s}$. Using Jensen's inequality, we know that the mean of the transformed variable, $\widetilde{w}_{A}^{s}$, is greater than (less than)

\footnotetext{
${ }^{36}$ Allowing for discounting, risk aversion, or aversion to intertemporal changes in wages would complicate notation without affecting the results.

${ }^{36}$ If $T$ is unknown but its distribution, $v(T)$, is known, then agents are assumed to compare the expected wage stream in the two jobs. In terms of equation (A2), the equivalent wage streams are given by $\widetilde{w}_{A}=\int \frac{W_{A}(T)}{T} v(T) d T$.
} 
the transformation of the mean, $\widetilde{w}_{A}$, if the transformation is convex (concave). Therefore, if the transformation is convex, the person is more likely to accept a job with wage growth (job A) when the supplement is available. 


\section{B Sample Used to Estimate Wage Growth}

This appendix provides results from Tables $1 \mathrm{a}$ through $3 \mathrm{~b}$ for the subsample of individuals with jobs beginning after the 18-month interview.

Table B1a

Summary Statistics at Baseline Interview

Full Sample

INDIVIDUALS WITH JOBS STARTING AFTER 18TH MONTH

\begin{tabular}{|c|c|c|c|c|c|}
\hline & \multirow[b]{2}{*}{ All } & \multirow[b]{2}{*}{ Control (IA) } & \multicolumn{3}{|c|}{ Experimental } \\
\hline & & & SSP Eligible & Tookup SSP & $\begin{array}{c}\text { Did Not } \\
\text { Take Up } \\
\text { SSP }\end{array}$ \\
\hline & (1) & (2) & \begin{tabular}{|l|} 
(3) \\
\end{tabular} & (4) & (5) \\
\hline \multicolumn{6}{|l|}{ Demographic } \\
\hline Age & $\begin{array}{r}31.0 \\
(0.13)\end{array}$ & $\begin{array}{r}30.9 \\
(0.19)\end{array}$ & $\begin{array}{r}31.0 \\
(0.19)\end{array}$ & $\begin{array}{r}30.8 \\
(0.26)\end{array}$ & $\begin{array}{r}31.3 \\
(0.26)\end{array}$ \\
\hline Speaks English & $\begin{array}{r}0.99 \\
(0.00)\end{array}$ & $\begin{array}{r}0.99 \\
(0.00)\end{array}$ & $\begin{array}{r}0.99 \\
(0.00)\end{array}$ & $\begin{array}{r}0.99 \\
(0.00)\end{array}$ & $\begin{array}{r}0.99 \\
(0.00)\end{array}$ \\
\hline Speaks French & $\begin{array}{r}0.15 \\
(0.01)\end{array}$ & $\begin{array}{r}0.15 \\
(0.01)\end{array}$ & $\begin{array}{r}0.15 \\
(0.01)\end{array}$ & $\begin{array}{r}0.16 \\
(0.01)\end{array}$ & $\begin{array}{r}0.14 \\
(0.01)\end{array}$ \\
\hline Never Married & $\begin{array}{r}0.49 \\
(0.01)\end{array}$ & $\begin{array}{r}0.50 \\
(0.01)\end{array}$ & $\begin{array}{r}0.49 \\
(0.01)\end{array}$ & $\begin{array}{r}0.48 \\
(0.02)\end{array}$ & $\begin{array}{r}0.50 \\
(0.02)\end{array}$ \\
\hline Number of Kids & $\begin{array}{r}1.63 \\
(0.01)\end{array}$ & $\begin{array}{r}1.61 \\
(0.02)\end{array}$ & $\begin{array}{r}1.65 \\
(0.02)\end{array}$ & $\begin{array}{r}1.61 \\
(0.03)\end{array}$ & $\begin{array}{r}1.68 \\
(0.03)\end{array}$ \\
\hline Less Than High School & $\begin{array}{r}0.49 \\
(0.01)\end{array}$ & $\begin{array}{r}0.48 \\
(0.01)\end{array}$ & $\begin{array}{r}0.49 \\
(0.01)\end{array}$ & $\begin{array}{r}0.44 \\
(0.02)\end{array}$ & $\begin{array}{r}0.54 \\
(0.02)\end{array}$ \\
\hline High School Graduate & $\begin{array}{r}0.51 \\
(0.01)\end{array}$ & $\begin{array}{r}0.52 \\
(0.01)\end{array}$ & $\begin{array}{r}0.51 \\
(0.01)\end{array}$ & $\begin{array}{r}0.56 \\
(0.02)\end{array}$ & $\begin{array}{r}0.46 \\
(0.02)\end{array}$ \\
\hline \multicolumn{6}{|l|}{ Employment } \\
\hline Initial Experience (months) & $\begin{array}{r}94.24 \\
(1.31)\end{array}$ & $\begin{array}{r}95.83 \\
(1.89)\end{array}$ & $\begin{array}{l}92.79 \\
(1.82)\end{array}$ & $\begin{array}{r}99.70 \\
(2.70)\end{array}$ & $\begin{array}{l}86.46 \\
(2.44)\end{array}$ \\
\hline Employed & $\begin{array}{r}0.28 \\
(0.01)\end{array}$ & $\begin{array}{r}0.30 \\
(0.01)\end{array}$ & $\begin{array}{r}0.26 \\
(0.01)\end{array}$ & $\begin{array}{r}0.32 \\
(0.02)\end{array}$ & $\begin{array}{r}0.20 \\
(0.01)\end{array}$ \\
\hline Employed Full Time & $\begin{array}{r}0.10 \\
(0.01)\end{array}$ & $\begin{array}{r}0.11 \\
(0.01)\end{array}$ & $\begin{array}{r}0.09 \\
(0.01)\end{array}$ & $\begin{array}{r}0.13 \\
(0.01)\end{array}$ & $\begin{array}{r}0.04 \\
(0.01)\end{array}$ \\
\hline Employed Part Time & $\begin{array}{r}0.18 \\
(0.01)\end{array}$ & $\begin{array}{r}0.19 \\
(0.01)\end{array}$ & $\begin{array}{r}0.17 \\
(0.01)\end{array}$ & $\begin{array}{r}0.19 \\
(0.01)\end{array}$ & $\begin{array}{r}0.15 \\
(0.01)\end{array}$ \\
\hline No Previous Work Experience & $\begin{array}{r}0.02 \\
(0.00)\end{array}$ & $\begin{array}{r}0.02 \\
(0.00)\end{array}$ & $\begin{array}{r}0.02 \\
(0.00)\end{array}$ & $\begin{array}{r}0.01 \\
(0.00)\end{array}$ & $\begin{array}{r}0.03 \\
(0.01)\end{array}$ \\
\hline Not Employed and Not Looking & $\begin{array}{r}0.46 \\
(0.01)\end{array}$ & $\begin{array}{r}0.44 \\
(0.01)\end{array}$ & $\begin{array}{r}0.48 \\
(0.01)\end{array}$ & $\begin{array}{r}0.41 \\
(0.02)\end{array}$ & $\begin{array}{r}0.55 \\
(0.02)\end{array}$ \\
\hline \# Individuals & 3,243 & 1,539 & 1,704 & 817 & 887 \\
\hline
\end{tabular}

NOTE: Standard errors in parentheses. 
Table B1b

Summary Statistics at Baseline Interview Employed at Baseline Interview INDIVIDUALS WITH JOBS STARTING AFTER 18TH MONTH

\begin{tabular}{|c|c|c|c|c|c|}
\hline & \multirow[b]{2}{*}{ All } & \multirow[b]{2}{*}{ Control (IA) } & \multicolumn{3}{|c|}{ Experimental } \\
\hline & & & SSP Eligible & Tookup SSP & $\begin{array}{c}\text { Did Not } \\
\text { Take Up } \\
\text { SSP }\end{array}$ \\
\hline & (1) & (2) & (3) & (4) & (5) \\
\hline \multicolumn{6}{|l|}{ Demographic } \\
\hline Age & $\begin{array}{r}32.7 \\
(0.25)\end{array}$ & $\begin{array}{r}32.8 \\
(0.35)\end{array}$ & $\begin{array}{r}32.6 \\
(0.36)\end{array}$ & $\begin{array}{r}31.5 \\
(0.45)\end{array}$ & $\begin{array}{r}34.3 \\
(0.59)\end{array}$ \\
\hline Speaks English & $\begin{array}{r}0.99 \\
(0.00)\end{array}$ & $\begin{array}{r}0.99 \\
(0.01)\end{array}$ & $\begin{array}{r}1.00 \\
(0.00)\end{array}$ & $\begin{array}{r}0.99 \\
(0.01)\end{array}$ & $\begin{array}{r}1.00 \\
(0.00)\end{array}$ \\
\hline Speaks French & $\begin{array}{r}0.14 \\
(0.01)\end{array}$ & $\begin{array}{r}0.15 \\
(0.02)\end{array}$ & $\begin{array}{r}0.14 \\
(0.02)\end{array}$ & $\begin{array}{r}0.15 \\
(0.02)\end{array}$ & $\begin{array}{r}0.12 \\
(0.02)\end{array}$ \\
\hline Never Married & $\begin{array}{r}0.44 \\
(0.02)\end{array}$ & $\begin{array}{r}0.44 \\
(0.02)\end{array}$ & $\begin{array}{r}0.45 \\
(0.02)\end{array}$ & $\begin{array}{r}0.47 \\
(0.03)\end{array}$ & $\begin{array}{r}0.41 \\
(0.04)\end{array}$ \\
\hline Number of Kids & $\begin{array}{r}1.60 \\
(0.03)\end{array}$ & $\begin{array}{r}1.58 \\
(0.04)\end{array}$ & $\begin{array}{r}1.62 \\
(0.04)\end{array}$ & $\begin{array}{r}1.57 \\
(0.05)\end{array}$ & $\begin{array}{r}1.70 \\
(0.07)\end{array}$ \\
\hline Less Than High School & $\begin{array}{r}0.43 \\
(0.02)\end{array}$ & $\begin{array}{r}0.43 \\
(0.02)\end{array}$ & $\begin{array}{r}0.43 \\
(0.02)\end{array}$ & $\begin{array}{r}0.36 \\
(0.03)\end{array}$ & $\begin{array}{r}0.54 \\
(0.04)\end{array}$ \\
\hline High School Graduate & $\begin{array}{r}0.57 \\
(0.02)\end{array}$ & $\begin{array}{r}0.57 \\
(0.02)\end{array}$ & $\begin{array}{r}0.57 \\
(0.02)\end{array}$ & $\begin{array}{r}0.64 \\
(0.03)\end{array}$ & $\begin{array}{r}0.46 \\
(0.04)\end{array}$ \\
\hline \multicolumn{6}{|l|}{ Employment } \\
\hline Initial Experience (months) & $\begin{array}{r}120.09 \\
(2.58)\end{array}$ & $\begin{array}{r}123.03 \\
(3.73)\end{array}$ & $\begin{array}{r}117.03 \\
(3.56)\end{array}$ & $\begin{array}{r}117.71 \\
(4.68)\end{array}$ & $\begin{array}{r}116.01 \\
(5.45)\end{array}$ \\
\hline Employed Full Time & $\begin{array}{r}0.34 \\
(0.02)\end{array}$ & $\begin{array}{r}0.35 \\
(0.02)\end{array}$ & $\begin{array}{r}0.33 \\
(0.02)\end{array}$ & $\begin{array}{r}0.40 \\
(0.03)\end{array}$ & $\begin{array}{r}0.22 \\
(0.03)\end{array}$ \\
\hline Employed Part Time & $\begin{array}{r}0.66 \\
(0.02)\end{array}$ & $\begin{array}{r}0.65 \\
(0.02)\end{array}$ & $\begin{array}{r}0.67 \\
(0.02)\end{array}$ & $\begin{array}{r}0.60 \\
(0.03)\end{array}$ & $\begin{array}{r}0.78 \\
(0.03)\end{array}$ \\
\hline \# Individuals & 892 & 455 & 437 & 262 & 175 \\
\hline
\end{tabular}

NOTE: Standard errors in parentheses. 
Table B2a

Observed Employment

Full Sample

INDIVIDUALS WITH JOBS STARTING AFTER 18TH MONTH

\begin{tabular}{|c|c|c|c|c|c|}
\hline & \multirow[b]{2}{*}{ All } & \multirow[b]{2}{*}{ Control (IA) } & \multicolumn{3}{|c|}{ Experimental } \\
\hline & & & SSP Eligible & Tookup SSP & $\begin{array}{c}\text { Did Not Take } \\
\text { Up SSP }\end{array}$ \\
\hline & (1) & (2) & (3) & (4) & (5) \\
\hline \multicolumn{6}{|l|}{ All Jobs } \\
\hline Average Employment (months) & $\begin{array}{l}18.22 \\
(0.24)\end{array}$ & $\begin{array}{l}17.18 \\
(0.34)\end{array}$ & $\begin{array}{l}19.17 \\
(0.33)\end{array}$ & $\begin{array}{l}26.12 \\
(0.42)\end{array}$ & $\begin{array}{l}12.76 \\
(0.39)\end{array}$ \\
\hline $\begin{array}{l}\text { Average Number of Jobs per } \\
\text { Worker }\end{array}$ & $\begin{array}{r}1.88 \\
(0.02)\end{array}$ & $\begin{array}{r}1.80 \\
(0.03)\end{array}$ & $\begin{array}{r}1.96 \\
(0.03)\end{array}$ & $\begin{array}{r}2.38 \\
(0.05)\end{array}$ & $\begin{array}{r}1.56 \\
(0.03)\end{array}$ \\
\hline \multicolumn{6}{|l|}{ Full-time Jobs } \\
\hline Average Employment (months) & $\begin{array}{l}11.81 \\
(0.23)\end{array}$ & $\begin{array}{r}9.67 \\
(0.30)\end{array}$ & $\begin{array}{l}13.73 \\
(0.34)\end{array}$ & $\begin{array}{l}22.65 \\
(0.45)\end{array}$ & $\begin{array}{r}5.52 \\
(0.29)\end{array}$ \\
\hline $\begin{array}{l}\text { Average Number of Jobs per } \\
\text { Worker }\end{array}$ & $\begin{array}{r}1.65 \\
(0.02)\end{array}$ & $\begin{array}{r}1.56 \\
(0.03)\end{array}$ & $\begin{array}{r}1.71 \\
(0.03)\end{array}$ & $\begin{array}{r}1.93 \\
(0.04)\end{array}$ & $\begin{array}{r}1.33 \\
(0.03)\end{array}$ \\
\hline \multicolumn{6}{|l|}{ Part-time Jobs } \\
\hline Average Employment (months) & $\begin{array}{r}8.49 \\
(0.20)\end{array}$ & $\begin{array}{r}9.66 \\
(0.31)\end{array}$ & $\begin{array}{r}7.43 \\
(0.26)\end{array}$ & $\begin{array}{r}5.46 \\
(0.32)\end{array}$ & $\begin{array}{r}9.24 \\
(0.38)\end{array}$ \\
\hline $\begin{array}{l}\text { Average Number of Jobs per } \\
\text { Worker }\end{array}$ & $\begin{array}{r}1.37 \\
(0.02)\end{array}$ & $\begin{array}{r}1.37 \\
(0.02)\end{array}$ & $\begin{array}{r}1.38 \\
(0.02)\end{array}$ & $\begin{array}{r}1.48 \\
(0.04)\end{array}$ & $\begin{array}{r}1.33 \\
(0.03)\end{array}$ \\
\hline $\begin{array}{l}\text { \# Individuals } \\
\text { \# Jobs } \\
\text { \# Full-time Jobs } \\
\text { \# Part-time Jobs }\end{array}$ & $\begin{array}{l}3,243 \\
5,677 \\
3,180 \\
2,502\end{array}$ & $\begin{array}{l}1,539 \\
2,547 \\
1,278 \\
1,271\end{array}$ & $\begin{array}{l}1,704 \\
3,130 \\
1,902 \\
1,231\end{array}$ & $\begin{array}{r}817 \\
1,877 \\
1,391 \\
487\end{array}$ & $\begin{array}{r}887 \\
1,253 \\
511 \\
744\end{array}$ \\
\hline
\end{tabular}

NOTE: Standard errors in parentheses. 
Table B2b

Observed Employment

Employed at Baseline Interview

INDIVIDUALS WITH JOBS STARTING AFTER 18TH MONTH

\begin{tabular}{|c|c|c|c|c|c|}
\hline & \multirow[b]{2}{*}{ All } & \multirow[b]{2}{*}{ Control (IA) } & \multicolumn{3}{|c|}{ Experimental } \\
\hline & & & SSP Eligible & Tookup SSP & $\begin{array}{c}\text { Did Not Take } \\
\text { Up SSP }\end{array}$ \\
\hline & (1) & (2) & (3) & (4) & $(5)$ \\
\hline \multicolumn{6}{|l|}{ All Jobs } \\
\hline Average Employment (months) & $\begin{array}{r}27.47 \\
(0.45)\end{array}$ & $\begin{array}{r}27.03 \\
(0.63)\end{array}$ & $\begin{array}{r}27.93 \\
(0.64)\end{array}$ & $\begin{array}{l}32.26 \\
(0.66)\end{array}$ & $\begin{array}{r}21.45 \\
(1.08)\end{array}$ \\
\hline $\begin{array}{l}\text { Average Number of Jobs per } \\
\text { Worker }\end{array}$ & $\begin{array}{r}2.20 \\
(0.04)\end{array}$ & $\begin{array}{r}2.09 \\
(0.06)\end{array}$ & $\begin{array}{r}2.32 \\
(0.06)\end{array}$ & $\begin{array}{r}2.65 \\
(0.09)\end{array}$ & $\begin{array}{r}1.82 \\
(0.08)\end{array}$ \\
\hline \multicolumn{6}{|l|}{ Full-time Jobs } \\
\hline Average Employment (months) & $\begin{array}{l}16.27 \\
(0.52)\end{array}$ & $\begin{array}{l}14.01 \\
(0.70)\end{array}$ & $\begin{array}{l}18.61 \\
(0.77)\end{array}$ & $\begin{array}{l}26.31 \\
(0.87)\end{array}$ & $\begin{array}{r}7.10 \\
(0.84)\end{array}$ \\
\hline $\begin{array}{l}\text { Average Number of Jobs per } \\
\text { Worker }\end{array}$ & $\begin{array}{r}1.80 \\
(0.04)\end{array}$ & $\begin{array}{r}1.68 \\
(0.06)\end{array}$ & $\begin{array}{r}1.91 \\
(0.06)\end{array}$ & $\begin{array}{r}2.08 \\
(0.08)\end{array}$ & $\begin{array}{r}1.43 \\
(0.08)\end{array}$ \\
\hline \multicolumn{6}{|l|}{ Part-time Jobs } \\
\hline Average Employment (months) & $\begin{array}{l}13.42 \\
(0.50)\end{array}$ & $\begin{array}{l}15.11 \\
(0.73)\end{array}$ & $\begin{array}{l}11.67 \\
(0.67)\end{array}$ & $\begin{array}{r}8.42 \\
(0.72)\end{array}$ & $\begin{array}{l}16.54 \\
(1.20)\end{array}$ \\
\hline $\begin{array}{l}\text { Average Number of Jobs per } \\
\text { Worker }\end{array}$ & $\begin{array}{r}1.50 \\
(0.03)\end{array}$ & $\begin{array}{r}1.52 \\
(0.04)\end{array}$ & $\begin{array}{r}1.49 \\
(0.04)\end{array}$ & $\begin{array}{r}1.49 \\
(0.06)\end{array}$ & $\begin{array}{r}1.49 \\
(0.07)\end{array}$ \\
\hline $\begin{array}{l}\text { \# Individuals } \\
\text { \# Jobs } \\
\text { \# Full-time Jobs } \\
\text { \# Part-time Jobs }\end{array}$ & $\begin{array}{r}892 \\
1,886 \\
963 \\
923\end{array}$ & $\begin{array}{l}455 \\
917 \\
434 \\
483\end{array}$ & $\begin{array}{l}437 \\
969 \\
529 \\
440\end{array}$ & $\begin{array}{l}262 \\
669 \\
428 \\
241\end{array}$ & $\begin{array}{l}175 \\
300 \\
101 \\
199\end{array}$ \\
\hline
\end{tabular}

NOTE: Standard errors in parentheses. 
Table B3a

Cox Proportional Hazard Model of Job Duration Full Sample

INDIVIDUALS WITH JOBS STARTING AFTER 18TH MONTH

\begin{tabular}{|c|c|c|c|c|c|c|}
\hline \multirow{3}{*}{ Control versus: } & \multicolumn{2}{|c|}{ All Job Exits } & \multicolumn{2}{|c|}{ Job-to-Job Exits } & \multicolumn{2}{|c|}{ Job-to-Unemployment Exits } \\
\hline & SSP & Take Up & $\mathbf{S S P}$ & Take Up & SSP & Take Up \\
\hline & (1) & (2) & (3) & (4) & (5) & (6) \\
\hline In SSP Group & $\begin{array}{c}-0.026 \\
(0.046)\end{array}$ & $\begin{array}{l}-0.107^{* *} \\
(0.053)\end{array}$ & $\begin{array}{c}0.186^{* * *} \\
(0.088)\end{array}$ & $\begin{array}{l}0.316^{* * *} \\
(0.094)\end{array}$ & $\begin{array}{r}-0.090 \\
(0.056)\end{array}$ & $\begin{array}{l}-0.278^{* * *} \\
(0.067)\end{array}$ \\
\hline Female & $\begin{array}{r}0.022 \\
(0.121)\end{array}$ & $\begin{array}{r}0.034 \\
(0.137)\end{array}$ & $\begin{array}{r}0.066 \\
(0.235)\end{array}$ & $\begin{array}{r}0.000 \\
(0.249)\end{array}$ & $\begin{array}{r}-0.017 \\
(0.144)\end{array}$ & $\begin{array}{r}0.036 \\
(0.169)\end{array}$ \\
\hline Speaks French & $\begin{array}{r}0.069 \\
(0.063)\end{array}$ & $\begin{array}{r}0.084 \\
(0.070)\end{array}$ & $\begin{array}{c}0.259^{* *} \\
(0.110)\end{array}$ & $\begin{array}{c}0.2722^{* *} \\
(0.119)\end{array}$ & $\begin{array}{l}-0.007 \\
(0.078)\end{array}$ & $\begin{array}{r}0.002 \\
(0.089)\end{array}$ \\
\hline Never Married & $\begin{array}{l}0.128^{* * * *} \\
(0.048)\end{array}$ & $\begin{array}{c}0.120{ }^{* *} \\
(0.055)\end{array}$ & $\begin{array}{r}0.063 \\
(0.090)\end{array}$ & $\begin{array}{r}0.059 \\
(0.099)\end{array}$ & $\begin{array}{c}0.1566^{* * *} \\
(0.059)\end{array}$ & $\begin{array}{c}0.159^{* *} \\
(0.068)\end{array}$ \\
\hline Number of Children & $\begin{array}{r}0.040 \\
(0.029)\end{array}$ & $\begin{array}{r}0.042 \\
(0.034)\end{array}$ & $\begin{array}{r}-0.062 \\
(0.058)\end{array}$ & $\begin{array}{r}-0.031 \\
(0.064)\end{array}$ & $\begin{array}{c}0.067 \\
(0.035)\end{array}$ & $\begin{array}{r}0.063 \\
(0.041)\end{array}$ \\
\hline High School Graduate & $\begin{array}{r}-0.004 \\
(0.047)\end{array}$ & $\begin{array}{r}-0.055 \\
(0.053)\end{array}$ & $\begin{array}{c}0.243^{* * * *} \\
(0.090)\end{array}$ & $\begin{array}{c}0.214^{* *} \\
(0.099)\end{array}$ & $\begin{array}{l}-0.118 \text { ** } \\
(0.056)\end{array}$ & $\begin{array}{l}-0.194^{* * *} \\
(0.065)\end{array}$ \\
\hline $\begin{array}{l}\text { \# Exits } \\
\text { Control } \\
\text { Experimental }\end{array}$ & & & & & & \\
\hline
\end{tabular}

NOTES:

(1) Standard errors in parentheses.

(2) Coefficient estimates are significant at the $10 \%(*), 5 \%(* *)$, or $1 \%(* * *)$ levels.

Table B3b

Cox Proportional Hazard Model of Job Duration Employed at Baseline Interview INDIVIDUALS WITH JOBS STARTING AFTER 18TH MONTH

\begin{tabular}{|c|c|c|c|c|c|c|}
\hline \multirow{3}{*}{ Control versus: } & \multicolumn{2}{|c|}{ All Job Exits } & \multicolumn{2}{|c|}{ Job-to-Job Exits } & \multicolumn{2}{|c|}{ Job-to-Unemployment Exits } \\
\hline & SSP & Take Up & SSP & Take Up & SSP & Take Up \\
\hline & (1) & (2) & (3) & (4) & (5) & (6) \\
\hline In SSP Group & $\begin{array}{r}0.023 \\
(0.087)\end{array}$ & $\begin{array}{r}-0.023 \\
(0.099)\end{array}$ & $\begin{array}{l}0.417^{* * * *} \\
(0.146)\end{array}$ & $\begin{array}{l}0.5611^{* * *} \\
(0.154)\end{array}$ & $\begin{array}{c}-0.192 \text { * } \\
(0.114)\end{array}$ & $\begin{array}{l}-0.448^{* * *} \\
(0.141)\end{array}$ \\
\hline Female & $\begin{array}{c}-0.188 \\
(0.234)\end{array}$ & $\begin{array}{l}-0.130 \\
(0.262)\end{array}$ & $\begin{array}{r}0.346 \\
(0.513)\end{array}$ & $\begin{array}{r}0.200 \\
(0.518)\end{array}$ & $\begin{array}{c}-0.473{ }^{*} \\
(0.265)\end{array}$ & $\begin{array}{l}-0.369 \\
(0.306)\end{array}$ \\
\hline Speaks French & $\begin{array}{r}-0.131 \\
(0.129)\end{array}$ & $\begin{array}{r}-0.096 \\
(0.141)\end{array}$ & $\begin{array}{r}0.041 \\
(0.197)\end{array}$ & $\begin{array}{r}0.075 \\
(0.209)\end{array}$ & $\begin{array}{r}-0.210 \\
(0.171)\end{array}$ & $\begin{array}{r}-0.186 \\
(0.192)\end{array}$ \\
\hline Never Married & $\begin{array}{c}0.158{ }^{*} \\
(0.092)\end{array}$ & $\begin{array}{c}0.192 \\
(0.102)\end{array}$ & $\begin{array}{r}0.234 \\
(0.151)\end{array}$ & $\begin{array}{r}0.223 \\
(0.162)\end{array}$ & $\begin{array}{r}0.110 \\
(0.120)\end{array}$ & $\begin{array}{r}0.165 \\
(0.135)\end{array}$ \\
\hline Number of Children & $\begin{array}{r}0.011 \\
(0.056)\end{array}$ & $\begin{array}{r}0.025 \\
(0.062)\end{array}$ & $\begin{array}{r}0.001 \\
(0.094)\end{array}$ & $\begin{array}{r}0.005 \\
(0.101)\end{array}$ & $\begin{array}{r}-0.008 \\
(0.072)\end{array}$ & $\begin{array}{r}0.016 \\
(0.081)\end{array}$ \\
\hline High School Graduate & $\begin{array}{c}0.174{ }^{*} \\
(0.093)\end{array}$ & $\begin{array}{r}0.077 \\
(0.102)\end{array}$ & $\begin{array}{c}0.342^{* *} \\
(0.157)\end{array}$ & $\begin{array}{r}0.229 \\
(0.168)\end{array}$ & $\begin{array}{r}0.085 \\
(0.119)\end{array}$ & $\begin{array}{c}-0.018 \\
(0.133)\end{array}$ \\
\hline $\begin{array}{l}\text { \# Exits } \\
\text { Control } \\
\text { Experimental }\end{array}$ & & & & & & \\
\hline
\end{tabular}

NOTES:

(1) Standard errors in parentheses.

(2) Coefficient estimates are significant at the $10 \%(*), 5 \%(* *)$, or $1 \%(* * *)$ levels. 


\section{References}

David Blau and Philip Kenneth Robins. Job Search Outcomes for the Employed and Unemployed. Journal of Political Economy, 98(3):637-55, June 1990.

Kenneth Burdett. A Theory of Employee Job Search and Quit Rates. American Economic Review, 68(1):212-20, March 1978.

David Card, Charles Michalopoulos, and Philip K. Robins. The Limits to Wage Growth: Measuring the Growth Rate of Wages For Recent Welfare Leavers. Number 8444 in NBER Working Paper Series. National Bureau of Economic Research, Inc., 2001.

Tricia Gladden and Christopher Taber. Wage Progression Among Less Skilled Workers. pages 160-92. 2000.

John C. Ham and Robert J. Lalonde. The Effect of Sample Selection and Initial Conditions in Duration Models: Evidence from Experimental Data on Training. Econometrica, 64(1):175-205, January 1996.

James J. Heckman, Lance Lochner, and Christopher Taber. Explaining Rising Wage Inequality: Explorations with a Dynamic General Equilibrium Model of Labor Earnings with Heterogeneous Agents. Review of Economic Dynamics, 1(1):1-58, January 1998.

James J. Heckman, Lance Lochner, and Ricardo Cossa. Learning-By-Doing Vs. On-the-Job Training: Using Variation Induced by the EITC to Distinguish Between Models of Skill Formation. Number 9083 in NBER Working Paper Series. National Bureau of Economic Research, Inc., June 2002.

James J. Heckman, Lance J. Lochner, and Petra E. Todd. Fifty Years of Mincer Earnings Regressions. Number 9732 in NBER Working Paper Series. National Bureau of Economic Research, Inc., May 2003.

Harry Holzer. Job Search by Employed and Unemployed Youth. Industry and Labor Relations Review, (40):601-11, jul 1987.

Thomas Lemieux. The 'Mincer Equation' Thirty Years After Schooling, Experience, and Earnings. Number 62 in Center for Labor Economics Working Paper Series. University of California, Berkeley, CA, 2003.

Jeremy Lise, Shannon Seitz, and Jeffrey Smith. Evaluating Search and Matching Models Using Experimental Data. University of Maryland, April 2005.

Charles Michalopoulos, Doug Tattrie, Cynthia Miller, Philip K. Robins, Pamela Morris, David Gyarmati, Cindy Redcross, Kelly Foley, and Reuben Ford. Making Work Pay. Social Research and Demonstration Corporation, 2002.

Jacob Mincer. Schooling, Experience, and Earnings. National Bureau of Economic Research, Inc., New York, NY, 1974. 